\title{
Dopamine D1 Receptor-Dependent Trafficking of Striatal NMDA Glutamate Receptors to the Postsynaptic Membrane
}

\author{
Anthone W. Dunah and David G. Standaert \\ Department of Neurology, Massachusetts General Hospital and Harvard Medical School, Boston, Massachusetts 02114
}

Recent work has shown substantial alterations in NMDA receptor subunit expression, assembly, and phosphorylation in the dopamine-depleted striatum of a rodent 6-hydroxydopamine model of Parkinson's disease. These modifications are hypothesized to result from the trafficking of NMDA receptors between subcellular compartments. Here we show that in rat striatal tissues the NR2A and NR2B subunits in the synaptosomal membrane, and not those in the light membrane and synaptic vesicle-enriched compartments, are tyrosine phosphorylated. The dopamine D1 receptor agonist SKF-82958 produces (1) an increase in NR1, NR2A, and NR2B proteins in the synaptosomal membrane fraction; (2) a decrease in NR1, NR2A, and NR2B proteins in the light membrane and synaptic vesicleenriched fractions; and (3) an increase in the tyrosine phosphorylation of NR2A and NR2B in the synaptosomal membrane compartment. The protein phosphatase inhibitor pervanadate reproduces the alterations in subcellular distribution and phos-

NMDA glutamate receptors are heteromeric ligand-gated ion channels assembled from two subunit families: NR1, which consists of eight recognized isoforms that are generated from alternative splicing of a single gene, and NR2, composed of NR2A, NR2B, NR2C, and NR2D, encoded by four distinct genes (Dingledine et al., 1999). In the CNS the properties of NMDA receptors are determined by their subunit composition, phosphorylation, and cellular localization. The composition of NMDA receptors substantially alters the pharmacology of the receptors, in particular their affinities for agonists and antagonists (Laurie and Seeburg, 1994; Lynch et al., 1994; Williams et al., 1994; Lynch and Gallagher, 1996). Both NR1 and NR2 subunits are phosphorylated; the NR1 subunit has several serine phosphorylation sites in the carboxy tail region (Hisatsune et al., 1997; Tingley et al., 1997), whereas the NR2 subunits are phosphorylated at tyrosine residues (Moon et al., 1994; Lau and Huganir, 1995; Dunah et al., 1998). Phosphorylation modulates the activation and deactivation kinetic properties of NMDA receptors as well as other properties (Wang and Salter, 1994; Chen and Leonard, 1996). In the brain, NMDA receptors are found both in the cytoplasm of neurons as well as at excitatory synapses (Petralia et al., 1994). At the

\footnotetext{
Received March 19, 2001; revised May 8, 2001; accepted May 15, 2001.

This work was supported by National Institutes of Health Grant NS34361 (D.G.S.) and a grant from The National Parkinson Foundation (A.W.D.). We thank Dr. Barry B. Wolfe for the generous gifts of NR1, NR2A, and NR2B antibodies; Dr. Morgan Sheng for the kind donation of $\alpha$-actinin-2 antibody; and Dr. Michael Wyszynski for very helpful comments on this manuscript.

Correspondence should be addressed to Dr. David G. Standaert, Massachusetts General Hospital, CNY B114-2000, Charlestown, MA 02129-4404. E-mail: standaert@helix.mgh.harvard.edu.
}

Copyright (C) 2001 Society for Neuroscience 0270-6474/01/215546-13\$15.00/0 phorylation, whereas the effects of the dopamine D1 receptor agonist are blocked by genistein, a protein tyrosine kinase inhibitor. Dopamine D1 receptor agonist treatment does not change the subcellular distribution of the AMPA receptor subunits GluR1 or GluR2/3 in the striatum and has no effect on cortical or cerebellar NMDA receptor subunits. These data reveal a rapid dopamine D1 receptor- and tyrosine kinasedependent trafficking of striatal NMDA receptors between intracellular and postsynaptic sites. The subcellular trafficking of striatal NMDA receptors may play a significant role both in the pathogenesis of Parkinson's disease and in the development of adverse effects of chronic dopaminergic therapy in parkinsonian patients.

Key words: glutamate receptor; NMDA receptor; dopamine receptor; subcellular compartment; receptor trafficking; tyrosine phosphorylation

postsynaptic membrane, NMDA receptors interact with components of the postsynaptic density, a large macromolecular complex containing both anchoring and signaling elements (Kornau et al., 1995; Kim et al., 1996; Wyszynski et al., 1997; Ziff, 1997; Lin et al., 1998). The mechanisms regulating the subcellular localization and targeting of glutamate receptors to postsynaptic sites are not well defined, but it is clear that the subcellular distribution of the subunits can be regulated by neuronal activity (Rao and Craig, 1997; Lissin et al., 1998; Roche et al., 2000; Zukin et al., 2000; Vissel et al., 2001).

NMDA receptors expressed by neurons in the striatum play an important role in the regulation of movement as they mediate the effects of excitatory inputs from the cerebral cortex and thalamus and exhibit physiologic interactions with dopaminergic input from the nigrostriatal pathway (Di Chiara et al., 1994). In animal models of Parkinson's disease, antagonists of NMDA receptors substantially potentiate the short-term therapeutic effect of dopaminergic agents (Klockgether and Turski, 1990; Morelli et al., 1992; Papa et al., 1993; Kaur and Starr, 1997) and are effective in attenuating the abnormal motor behaviors produced by chronic dopaminergic treatment (Papa et al., 1995; Marin et al., 1996; Blanchet et al., 1997). Recent evidence suggests that the basis for the development of these abnormal motor behaviors may be that long-term treatment with dopaminergic agents modifies the properties of striatal NMDA receptors (Engber et al., 1994; Papa et al., 1995; Marin et al., 1996; Papa and Chase, 1996; Chase et al., 1998).

Recently, we showed that in rats with unilateral 6-hydroxydopamine (6-OHDA) lesions of the nigrostriatal pathway, which serves as a model of Parkinson's disease, there is a selective 
reduction in NMDA heteromers composed of NR1/NR2B subunits in the synaptosomal membranes of the dopamine-depleted striatum (Dunah et al., 2000a). In addition, the serine phosphorylation of NR1 and the tyrosine phosphorylation of NR2B, but not NR2A, are decreased. The alterations were observed only in membrane preparations and not in total striatal homogenate, suggesting a redistribution of NMDA receptor subunits among subcellular compartments. Chronic treatment of lesioned rats with levodopa (L-3,4-dihydroxyphenylalanine) normalized the abundance of the NMDA receptor subunits and increased the phosphorylation of NR1 and NR2 subunits (Dunah et al., 2000a).

On the basis of these observations we hypothesized that the dopamine-dependent phosphorylation of striatal NMDA receptors might be the trigger signal for the trafficking of NMDA receptors from intracellular compartments to the postsynaptic density. In the present study, biochemical protein fractionation, quantitative immunoprecipitation, and immunoblot methods were used to examine the distribution and phosphorylation of NMDA receptors in distinct subcellular compartments of acutely dissected rat striatum and the effect of treatment with pharmacologic agents affecting dopamine receptors or protein phosphorylation.

\section{MATERIALS AND METHODS}

Antibodies and pharmacological agents. The subunit-specific monoclonal NR1 (Luo et al., 1997), polyclonal NR2A (Wang et al., 1995), and monoclonal NR2B (Wang et al., 1995) antibodies were generous gifts from Dr. Barry B. Wolfe, Georgetown University (Washington, DC). The polyclonal $\alpha$-actinin-2 antibody (Wyszynski et al., 1997) was a kind donation from Dr. Morgan Sheng, Harvard Medical School (Boston, MA). The following antibodies were obtained from commercial sources: monoclonal PSD-95 (K28/43; Upstate Biotechnology, Lake Placid, NY); polyclonal NSF ( $N$-ethylmaleimide-sensitive fusion protein) rabbit serum (Synaptic Systems GmbH, Gottingen, Germany); polyclonal GluR1 and GluR2/3 (Chemicon, Temecula, CA); monoclonal syntaxin and synaptophysin (Sigma/RBI, St. Louis, MO/Natick, MA); monoclonal calnexin (Santa Crux Biotechnology, Santa Cruz, CA); monoclonal antiphosphotyrosine (PY20) and recombinant anti-phosphotyrosine monoclonal (RC20) (Transduction Laboratories, Lexington, K Y); horseradish peroxidase-linked goat anti-rabbit and horseradish peroxidase-linked goat anti-mouse (Jackson ImmunoResearch Laboratories, West Grove, PA). The drugs used for treatment of striatal tissues were purchased from the following sources: SKF-82958, SKF-38393, and quinpirole, Sigma/ RBI; genistein, Calbiochem; sodium orthovanadate, Acros Organics (Geel, Belgium); hydrogen peroxide, Fisher Scientific (Houston, TX).

Preparation and treatment of dissected rat brain tissues. Experimental protocols involving the use of vertebrate animals were approved by the Massachusetts General Hospital Subcommittee on Research Animal Care and met National Institutes of Health guidelines.

The brains of male Sprague Dawley rats weighing 150-200 gm were removed after decapitation. The striata were dissected and crosschopped at $200 \mu \mathrm{M}$ into slices with a McIlwain mechanical tissue chopper in Krebs' buffer [containing (in $\mathrm{mM}$ ) $118 \mathrm{NaCl}, 4.7 \mathrm{KCl}, 2 \mathrm{CaCl}, 1.2$ $\mathrm{MgSO}_{4}$, and $\left.1.2 \mathrm{KH}_{2} \mathrm{PO}_{4}\right]$ that had been equilibrated with $95 \% \mathrm{O}_{2} / 5 \%$ $\mathrm{CO}_{2}$. The striatal tissues were incubated in the absence (control) or presence (treatment) of SKF-82958 (50 $\mu \mathrm{M})$, SKF-38393 (100 $\mu \mathrm{M})$, quinpirole $(100 \mu \mathrm{M})$, pervanadate (sodium orthovanadate; $200 \mu \mathrm{M}$ ), or genistein $(100 \mu \mathrm{M})$ in Krebs' buffer at $37^{\circ} \mathrm{C}$ for $10 \mathrm{~min}$ with gentle agitation. Tissues were collected by centrifugation at $700 \times g$ at $4^{\circ} \mathrm{C}$ and were subjected to subcellular biochemical fractionation. A stock solution of the pervanadate was prepared as described previously (Dunah et al., 1998).

Subcellular fractionation of rat brain tissues. Biochemical fractionation was performed as described previously (Lin et al., 1998; Wyszynski et al., 1998) with minor modifications to allow for the immunoprecipitation of tyrosine-phosphorylated proteins. Dounce homogenates $(\mathrm{H})$ of the pellets in ice-cold TEVP buffer [containing (in mM) 10 Tris- $\mathrm{HCl}, \mathrm{pH} \mathrm{7.4,5}$ $\mathrm{NaF}, 1 \mathrm{Na}_{3} \mathrm{VO}_{4}, 1 \mathrm{EDTA}$, and 1 EGTA] containing $320 \mathrm{~mm}$ sucrose was centrifuged at $1000 \times g$ to remove nuclei and large debris (P1). The supernatant $(\mathrm{S} 1)$ was centrifuged at $10,000 \times g$ to obtain a crude synaptosomal fraction (P2) and subsequently was lysed hypo-osmotically and centrifuged at $25,000 \times g$ to pellet a synaptosomal membrane fraction (LP1). Then the resulting supernatant (LS1) was centrifuged at $165,000 \times g$ to obtain a synaptic vesicle-enriched fraction (LP2). Concurrently, the supernatant (S2) above the crude synaptosomal fraction (P2) was centrifuged at $165,000 \times g$ to obtain a cytosolic fraction (S3) and a light membrane/microsome-enriched fraction (P3; hereafter referred to as light membrane). After each centrifugation the resulting pellet was rinsed briefly with ice-cold TEVP buffer before subsequent fractionations to avoid possible crossover contamination.

Denaturing conditions of protein solubilization for phosphorylation studies. The striatal extracts resulting from subcellular fractionation were solubilized with $1 \%$ SDS in TEVP buffer and centrifuged at $15,000 \times g$ for $5 \mathrm{~min}$ in a microcentrifuge. Protein concentrations in the supernatants were determined with the Bio-Rad Protein Assay Kit (Hercules, CA) and used for immunoblot and immunoprecipitation studies.

Precoupling antibodies to protein A-Sepharose. The monoclonal antiphosphotyrosine (PY20) antibody was incubated with protein A-Sepharose beads at a concentration of $20 \mu \mathrm{g}$ of antibody per $50 \mu \mathrm{l}$ of hydrated protein A-Sepharose beads for $2 \mathrm{hr}$ at room temperature in 100 mM sodium borate, $\mathrm{pH} 8.0$, with gentle rotation. The beads were washed with $100 \mathrm{~mm}$ sodium borate, $\mathrm{pH} 8.0$, and used for immunoprecipitation.

Immunoprecipitation. The solubilized protein samples were diluted 20-fold with immunoprecipitation buffer [containing (in $\mathrm{mm}$ ) $150 \mathrm{NaCl}$, $50 \mathrm{Na}_{3} \mathrm{SO}_{4}, \mathrm{pH} 7.2$, and 2 EDTA, plus $1 \%$ sodium deoxycholate and $1 \%$ Triton $\mathrm{X}-100]$. The diluted samples were incubated with $50 \mu \mathrm{l}$ of the anti-phosphotyrosine antibody-coupled protein A-Sepharose beads for each $100 \mu \mathrm{g}$ of protein for $3 \mathrm{hr}$ in a cold room with gentle rotation. The immunoprecipitates were washed three times with ice-cold immunoprecipitation buffer after brief centrifugations and were resuspended in a suitable volume of loading buffer (62.5 mM Tris-HCl, pH 6.8, 2\% SDS, 50 mM DTT, and $7.5 \%$ glycerol). Samples were resolved on SDS-PAGE and immunoblotted for NR1, NR2A, and NR2B proteins.

Gel electrophoresis, quantitative immunoblotting, and statistical analysis. SDS-PAGE and the transfer of separated proteins to polyvinylidene difluoride (PVDF) membrane were performed as described previously (Wang et al., 1995; Dunah et al., 1996; Luo et al., 1996). For protein separation, 7.5 and $12.5 \%$ polyacrylamide gels were used; the concentration of antibodies used for immunoblotting was $1-2 \mu \mathrm{g} / \mathrm{ml}$. For the quantification of proteins in subcellular fractionation experiments, equal amounts $(10 \mu \mathrm{g})$ of protein from each fraction were loaded into each lane of the gel. For analysis of tyrosine phosphorylation, $5 \mu \mathrm{g}$ of each input sample and $40 \mu \mathrm{g}$ of the corresponding precipitated pellet were loaded in adjacent lanes on the same gel. Bands were visualized on film by enhanced chemiluminescence, and their net intensities were quantified via computer-assisted densitometry (Kodak 1-D System, Rochester, NY). The net intensities of the bands were expressed as a percentage of that in the control striatum. The resulting values were used to calculate group means and reported as means \pm SEM. Differences between groups were analyzed by ANOVA with post hoc tests (Scheffe's). For all of the analyses, statistical significance was taken to be $p<0.05$.

\section{RESULTS}

\section{Characterization of subcellular compartments}

A biochemical fractionation approach (Fig. 1 $A$ ) was used to isolate subcellular compartments from brain tissues, and the effectiveness of the subcellular fractionation procedure was evaluated in the striatum by the use of protein markers for subcellular compartments (Fig. 1B). Synaptophysin, a synaptic vesicle membrane protein believed to participate in the fusion of synaptic vesicles to the presynaptic membrane (Devoto and Barnstable, 1987), was found to be highly concentrated in the synaptic vesicleenriched fraction ( $L P 2$, lane 9$)$. This protein was also present at lower levels in both the light membrane (P3, lane 5) and synaptosomal membrane (LP1, lane 7) fractions. Syntaxin, a protein that interacts with synaptotagmin and participates in the docking of synaptic vesicles (Bennett et al., 1992; Barinaga, 1993), was enriched in both the light membrane (P3, lane 5) and synaptic vesicle-enriched (LP2, lane 9) fractions, whereas much lower levels were present in the synaptosomal membrane compartment (LP1, lane 7). The calcium-binding protein calnexin, known to 

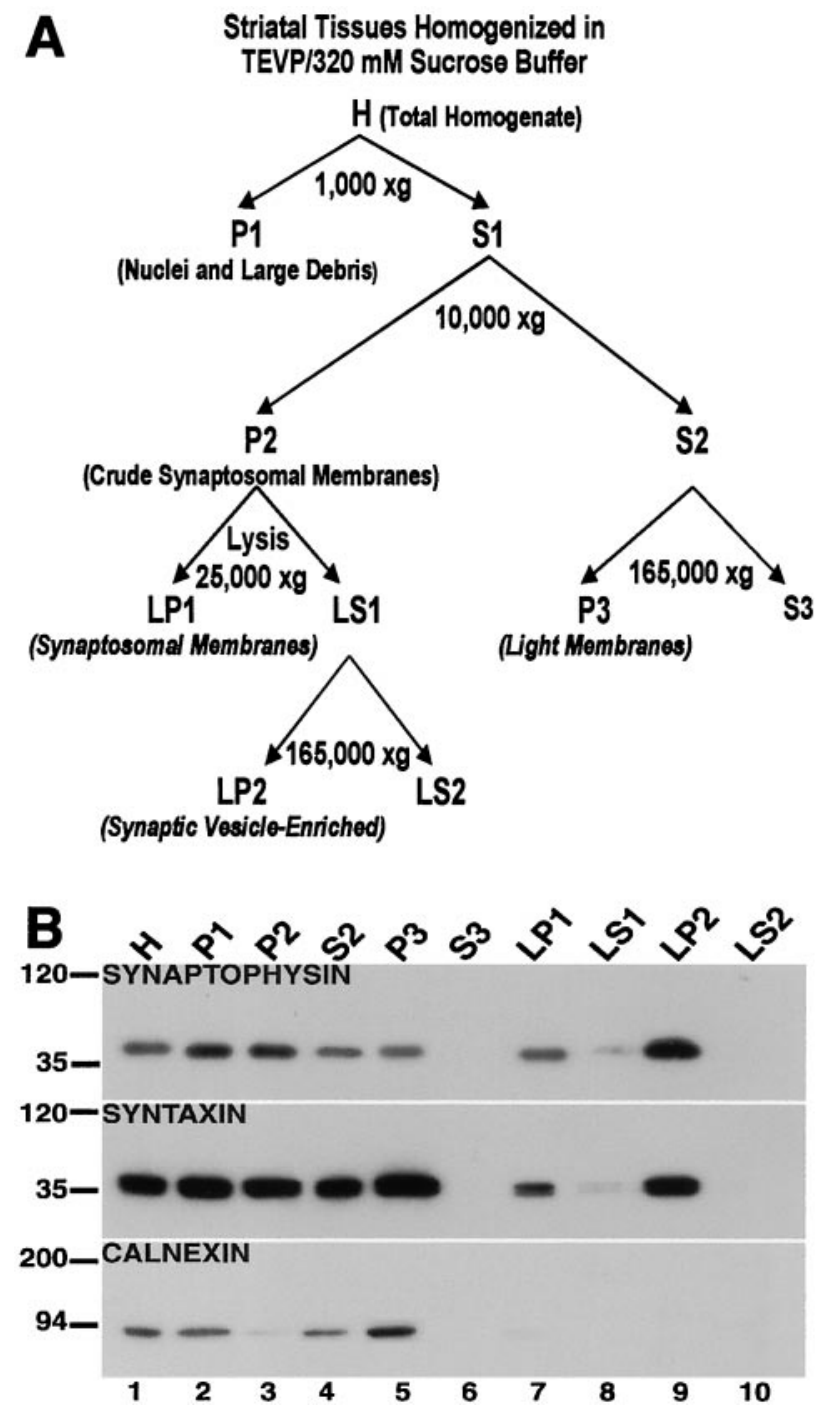

Figure 1. Characterization of fractionated subcellular compartments of the striatum. $A$, Schematic for the biochemical fractionation. The procedure for the subcellular separation of proteins as depicted in this schematic is described in Materials and Methods. B, Characterization of subcellular compartments. The isolated biochemical fractions from striatal tissues were separated by SDS-PAGE, and the blots were probed with antibodies against synaptophysin (top), syntaxin (middle), and calnexin (bottom). Synaptophysin is highly concentrated in the synaptic vesicleenriched fraction ( $L P 2$, lane 9); syntaxin is enriched in the light membrane (P3, lane 5) and synaptic vesicle-enriched ( LP2, lane 9$)$ fractions compared with the synaptosomal membrane (LP1, lane 7); and calnexin is found in the light membrane fraction ( $P 3$, lane 5), but not in the synaptosomal membrane (LP1, lane 7) nor synaptic vesicle-enriched (LP2, lane 9) fractions.

interact with newly synthesized glycoproteins in the endoplasmic reticulum (David et al., 1993), was present in the light membrane compartment (P3, lane 5) but was not detected in the synaptosomal membrane (LP1, lane 7) and/or synaptic vesicle-enriched (LP2, lane 9) fractions.

\section{Subcellular distribution of NMDA receptor proteins}

The expression of NMDA receptor subunits in various subcellular compartments was investigated in rat striatal tissues that were homogenized immediately after dissection (Fig. 2). The NR1, $\mathrm{NR} 2 \mathrm{~A}$, and NR2B subunits were found in the light membrane (P3, lane 5), synaptosomal membrane (LP1, lane 7), and synaptic vesicle-enriched ( $L P 2$, lane 9) fractions. As expected, these proteins were also present in the total homogenate $(H$, lane 1$)$; cell soma, nuclei, and nuclei-associated membrane (P1, lane 2); crude synaptosomal membrane $(P 2$, lane 3$)$; and the low-speed supernatant (S2, lane 4$)$ fractions; S2 is the parent fraction from which P3 is derived. However, the NMDA subunits were not detectable in the cytosolic or soluble subcellular fractions (S3, LS1, LS2; lanes $6,8,10$, respectively). In a similar experiment the subcellular distribution of NMDA receptors in the cerebral cortex and cerebellum also was investigated (Fig. 2, see cortex and cerebellum). The localization of NMDA receptor subunits NR1, NR2A, and $\mathrm{NR} 2 \mathrm{~B}$ in these rat brain regions was similar to what was observed in the striatum (Fig. 2, see striatum). As anticipated, the NR2B subunit was not detected in the rat cerebellum, and this concurs with previous studies showing the absence of NR2B expression in this region (Monyer et al., 1994; Wang et al., 1995).

Using the same biochemical fractions, we also examined the subcellular distribution of postsynaptic density-95 protein (PSD95) and $\alpha$-actinin-2, proteins that interact with NMDA receptors; $N$-ethylmaleimide-sensitive fusion protein (NSF), a protein that interacts with AMPA receptors; and total phosphotyrosine (PY) proteins (Fig. 2). The PSD-95 protein and phosphotyrosine proteins were confined to the crude extracts and the membrane compartments, exhibiting a subcellular expression profile similar to the NMDA subunits, except that PSD-95 and phosphotyrosine proteins were not detected in the synaptic vesicle-enriched fraction (LP2, lane 9). $\alpha$-Actinin-2 and NSF showed a wider subcellular distribution, because they were found in both the membrane and cytosolic subcellular fractions of the striatum (Fig. 2). In the cortex and cerebellum PSD-95, $\alpha$-actinin-2, and NSF showed a subcellular distribution profile similar to that of the striatum (Fig. 2 ), except that $\alpha$-actinin-2 expression was found to be very low in the cerebellum and was detected only in the light membrane fraction (cerebellum; P3, lane 5).

\section{Differential subcellular localization of tyrosine- phosphorylated NMDA receptor subunits in the rat brain}

The tyrosine phosphorylation of NMDA receptors in distinct striatal compartments was investigated by immunoprecipitating fractionated protein extracts with anti-phosphotyrosine antibodies and by immunoblotting samples of the input and pellet for NMDA subunits (Fig. 3). In accord with previous studies, tyrosine phosphorylation of NR1 was not detected in any subcellular compartment (Lau and Huganir, 1995; Dunah et al., 2000a). However, tyrosine-phosphorylated striatal NR2A and NR2B subunits were present in the total homogenate $(H$, lane 2$)$, nuclei and large debris (P1, lane 4), crude synaptosomal membrane (P2, lane 6), and synaptosomal membrane (LP1, lane 14) fractions. Interestingly, the NR2A and NR2B subunits present in the light membrane (P3, lane 10) and synaptic vesicle-enriched (LP2, lane 12) fractions of the striatum did not exhibit detectable tyrosine phosphorylation, even with longer exposure periods. Similar results were obtained in the cerebral cortex and cerebellum, except that the NR2B subunit was not detectable in the cerebellum (Fig. 3, see cortex and cerebellum).

\section{A dopamine D1 receptor agonist alters the subcellular distribution and phosphorylation of striatal NMDA receptors}

The effect of dopamine receptor activation on the subcellular localization of NMDA receptors was studied by treating rat 

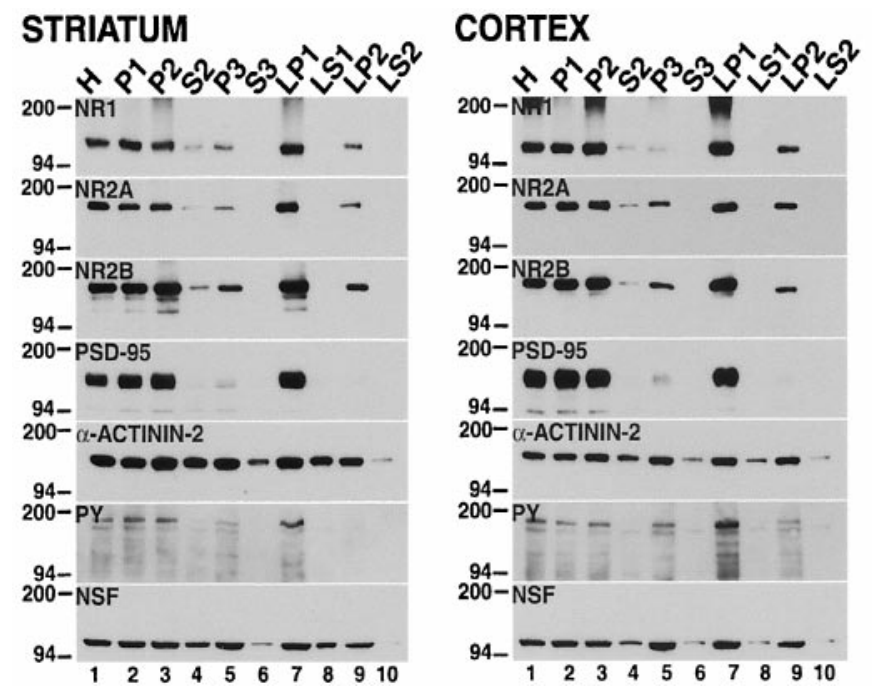

Figure 2. NMDA receptor subunits are distributed differentially between subcellular compartments in the rat brain. The tissue samples from the striatum, cortex, and cerebellum were homogenized immediately after dissection, separated into different biochemical fractions as described in Materials and Methods, and resolved on SDS-polyacrylamide gels. Total protein $(10 \mu \mathrm{g})$ from each fraction was loaded in each lane. The blots were probed with anti-NR1, anti-NR2A, anti-NR2B, antiPSD-95, anti- $\alpha$-actinin-2, anti-phosphotyrosine $(P Y)$, and anti-NSF antibodies. $H$, Total homogenate; $P 1$, nuclei and large debris; $P 2$, crude synaptosomal fraction; $P 3$, light membrane fraction; $L P 1$, synaptosomal membrane fraction; $L P 2$, synaptic vesicle-enriched fraction. $S 2, S 3, L S 1$, and $L S 2$ are supernatants from $P 2, P 3, L P 1$, and $L P 2$, respectively. The positions and sizes of molecular weight markers are indicated in kilodaltons. striatal tissues with specific agonists. These experiments were performed on tissues incubated in vitro with the pharmacologic agents for $10 \mathrm{~min}$. This treatment time was selected on the basis of the earlier studies of Snyder et al. (1998). Similar results were obtained by using a shorter 5 min incubation period (data not shown). The controls for these experiments were tissues incubated under identical in vitro conditions without the addition of pharmacologic agents. A comparison of the data obtained from these control incubations with those described above from tissues processed immediately after dissection indicated that the incubation alone did not alter either the subcellular distribution of the proteins that were examined or the tyrosine phosphorylation of NR2A and NR2B.

Treatment with SKF-82958, a dopamine D1 receptor full agonist (Figs. 4, 5), produced significant reductions in the abundance of NR1, NR2A, and NR2B proteins in the light membrane (Figs. 4A, 5, P3) fraction (NR1, $28 \pm 5 \%$; NR2A, $25 \pm 4 \%$; $\mathrm{NR} 2 \mathrm{~B}, 9 \pm 5 \%$; all values expressed as a percentage of control) and the synaptic vesicle-enriched (Figs. 4A, 5, LP2) fraction (NR1, $27 \pm 4 \%$; NR2A, $32 \pm 4 \%$; NR2B, $15 \pm 7 \%$ ). At the same time there was a marked increase in NR1 (146 $\pm 5 \%)$, NR2A $(150 \pm 4 \%)$, and NR2B $(158 \pm 8 \%)$ subunits in the synaptosomal membrane (Figs. 4A, 5, LP1) fraction. There were no significant changes in the relative levels of PSD-95, $\alpha$-actinin-2, and NSF in the different compartments after SKF-82958 treatment, but there was an apparent elevation of protein tyrosine phosphorylation, especially in the synaptosomal membrane (LP1) fraction (Fig. $4 A$, Table 1).

The effect of SKF-82958 treatment on tyrosine phosphorylation of the NMDA receptors present in the striatal compartments was determined by precipitating phosphotyrosine proteins from isolated fractions and probing them with NMDA receptor subunit-specific antibodies (Fig. 4B1,B2, Table 2). SKF-82958 produced an increase in tyrosine-phosphorylated NR2A and NR2B subunits in the synaptosomal membrane (LP1, lanes 26, 28 ) compartment to $154 \pm 5$ and $161 \pm 6 \%$, respectively (values expressed as a percentage of control). A similar increase in tyrosine-phosphorylated NR2A and NR2B subunits was observed in the total homogenate $(H$, lanes 2,4$)$, nuclei and large debris $(P 1$, lanes 6,8$)$, and crude synaptosomal membrane $(P 2$, lanes 10, 12) fractions (Fig. 4B1, Table 2). Tyrosinephosphorylated NR2A and NR2B subunits were not detected in the light membrane (P3, lanes 18,20$)$ and synaptic vesicleenriched (LP2, lanes 34, 36 ) fractions (Fig. 4B1,B2).

Similar experiments were performed with rat cortical and cerebellar tissues. Treatment of these tissues with SKF-82958 produced no apparent alterations in the subcellular distribution of NR1, NR2A, or NR2B subunits. The tyrosine phosphorylation of these NMDA subunits in the various subcellular compartments of the cortex and cerebellum also was unchanged after treatment with the dopamine D1 receptor agonist (data not shown).

In another experiment SKF-38393, a partial agonist of the dopamine D1 receptor, was used to treat striatal tissues. With this pharmacologic agent there was no alteration in the subcellular distribution (Table 1) or tyrosine phosphorylation (Table 2) of striatal NMDA receptors. Similarly, the effects of quinpirole, a dopamine D2 receptor agonist also were examined, and quinpirole produced no significant changes in the subcellular localization of NR1, NR2A, and NR2B receptors (Fig. 6A, Table 1) or the phosphorylation of NR2A and NR2B subunits at tyrosine residues (Fig. 6B1,B2, Table 2).

\section{Dopamine D1 receptor agonist does not alter the subcellular distribution or phosphorylation of striatal AMPA receptors}

The effect of the dopamine D1 receptor agonist SKF-82958 on the subcellular localization and phosphorylation of striatal AMPA receptor subunits GluR1 and GluR2/3 was investigated (Fig. 7). In control tissues (Fig. $7 A$, lanes designated $C$ ) the AMPA receptor subunits exhibited a distribution profile similar to that of the NMDA receptor subunits in that they were abundant in the synaptosomal membrane (LP1) but also were found in the light membrane (P3) and synaptic vesicle-enriched (LP2) fractions (Fig. 7A). Like the NMDA receptors, the GluR1 and GluR2/3 subunits found in the synaptosomal membrane (LP1) fraction were tyrosine phosphorylated, whereas those present in the light membrane (P3) and synaptic vesicle-enriched (LP2) fractions were not phosphorylated (Fig. 7B1,B2). Interestingly, treatment with SKF-82958 produced no alterations in either the subcellular distribution (Fig. $7 A$ ) or the tyrosine phosphorylation of the GluR1 and GluR2/3 subunits (Fig. 7B1,B2). 


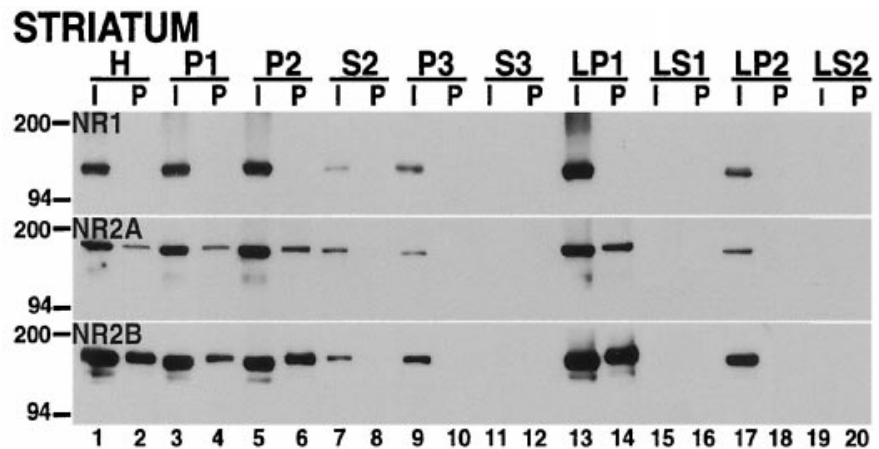

CORTEX

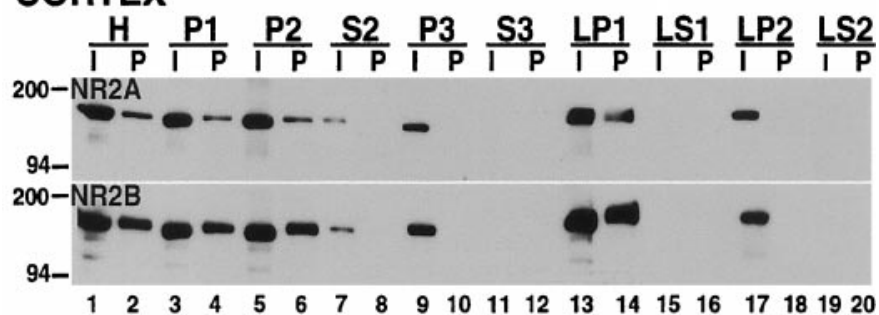

\section{CEREBELLUM}

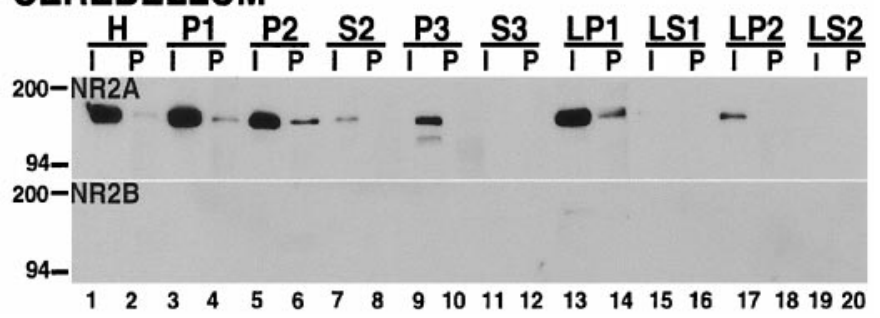

Figure 3. NMDA receptors present in the synaptosomal membrane fraction, but not those in the light membrane and synaptic vesicleenriched compartments, are tyrosine phosphorylated. Samples from rat striatum (top), cortex (middle), and cerebellum (bottom) were homogenized immediately after dissection, fractionated, solubilized, and immunoprecipitated with anti-phosphotyrosine antibody. The inputs (I; lanes 1 , $3,5,7,9,11,13,15,17,19 ; 5 \mu \mathrm{g})$ and pellets $(P$; lanes $2,4,6,8,10,12,14$, $16,18,20 ; 40 \mu \mathrm{g}$ ) were separated on SDS-PAGE gels, and the blots were probed with anti-NR1, anti-NR2A, and anti-NR2B antibodies. Tyrosinephosphorylated NR2A and NR2B subunits were detected in LP1 (lane 13), but not in P3 (lane 10) and LP2 (lane 18) fractions.

Inhibition of protein phosphatases alters the subcellular localization and phosphorylation of striatal NMDA receptors

To determine whether enhanced protein phosphorylation was sufficient to produce a redistribution of NMDA receptor subunits among subcellular compartments, we treated striatal tissues with pervanadate, a protein phosphatase inhibitor. Both control and treated tissues were fractionated and immunoblotted for NMDA receptors as well as for PSD-95, $\alpha$-actinin-2, NSF, and phosphotyrosine proteins (Fig. $8 A$ ). Pervanadate produced marked reductions in the levels of NR1, NR2A, and NR2B found in the light membrane (P3) fraction (NR1, $11 \pm 6 \%$; NR2A, $6 \pm 5 \%$; NR2B, $2 \pm 4 \%$ ) and synaptic vesicle-enriched (LP2) fraction $(\mathrm{NR} 1,21 \pm 5 \%$; NR2A, $17 \pm 6 \%$; NR2B, $11 \pm 5 \%)$ and a concomitant increase in NR1 $(165 \pm 5 \%)$, NR2A $(142 \pm 4 \%)$, and NR2B (179 $\pm 5 \%)$ in the synaptosomal membrane (LP1) fraction. There were no significant changes in the subcellular distribution of PSD-95, $\alpha$-actinin-2, and NSF (Fig. 8A, Table 1).

As shown in Figure $8 B 2$ and Table 2, the treatment of striatal

\section{SKF-82958}
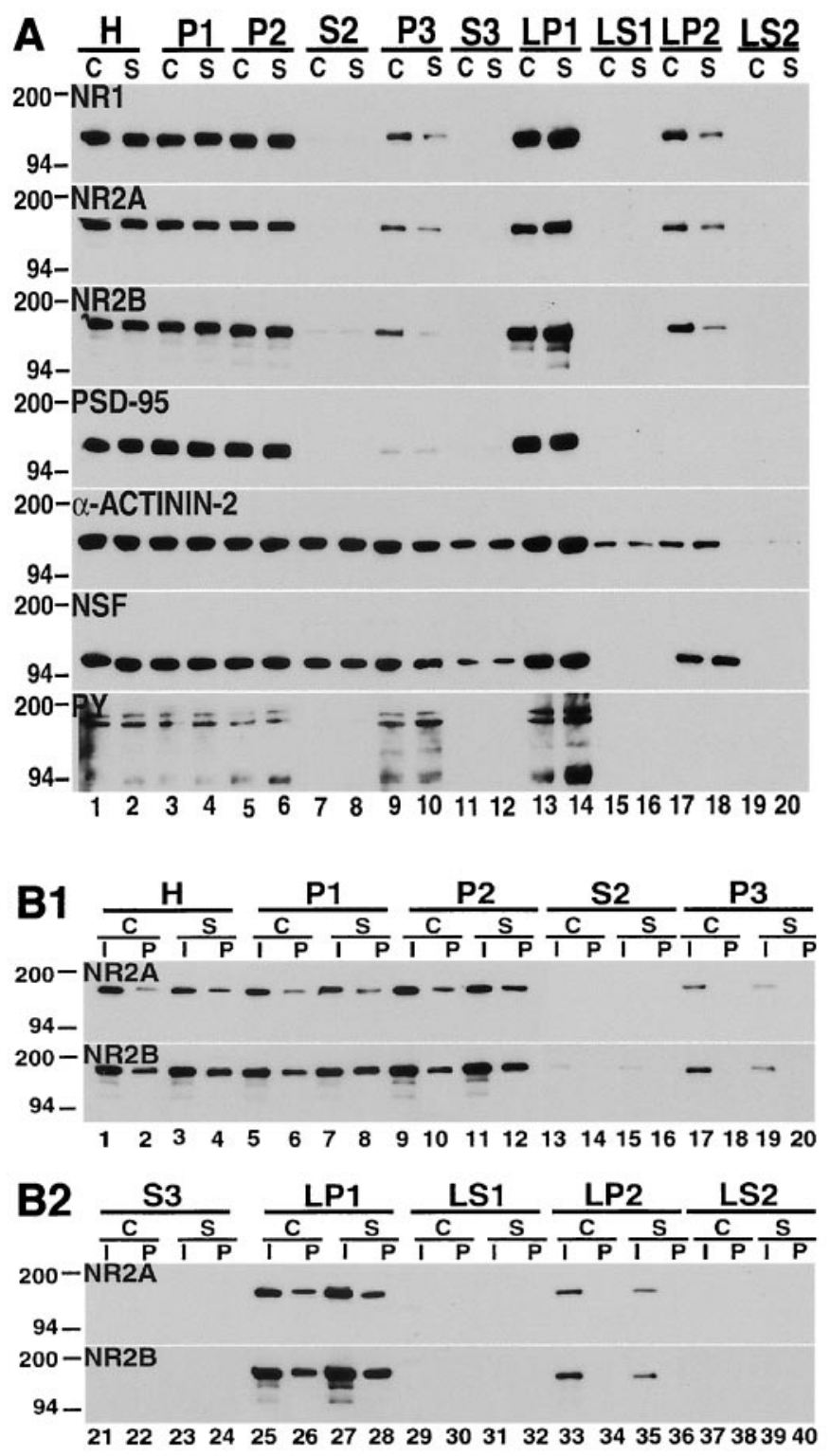

Figure 4. The dopamine D1 receptor agonist SKF-82958 produces subcellular redistribution and an increase in the tyrosine phosphorylation of striatal NMDA receptors. $A$, Subcellular distribution. Samples from tissues that were incubated for $10 \mathrm{~min}$ under control conditions $(C)$ or with $50 \mu \mathrm{M} \mathrm{SKF-82958}$ $(S)$ were subjected to biochemical fractionation. The subcellular fractions were resolved by SDS-PAGE, and the blots were probed with NR1, NR2A, NR2B, PSD-95, $\alpha$-actinin-2, NSF, and anti-phosphotyrosine $(P Y)$ antibodies. SKF-82958 decreased NR1, NR2A, and NR2B in P3 (lane 10) and LP2 (lane 18) fractions; it increased these subunits in LP1 (lane 14), and it increased phosphotyrosine proteins $(P Y) . B 1, B 2$, Tyrosine phosphorylation. The subcellular-fractionated samples from control $(C)$ and SKF-82958-treated $(S)$ striatal tissues were immunoprecipitated with anti-phosphotyrosine antibody and immunoblotted with anti-NR2A and anti-NR2B. The inputs $(I)$ and pellets $(P)$ for each biochemical fraction are indicated across the top of the figure. SKF-82958 increased tyrosine-phosphorylated NR2A and NR2B in H (lane 4), P1 (lane 8), P2 (lane 12), and LP1 (lane 28) fractions.

tissues with pervanadate also produced an increase in the tyrosine phosphorylation of the NR2A $(183 \pm 7 \%)$ and NR2B $(181 \pm 5 \%)$ subunits present in the synaptosomal membrane (LP1) fraction. However, even under this condition no tyrosine phosphorylation of the NR2A and NR2B subunits remaining in 
SKF-82958
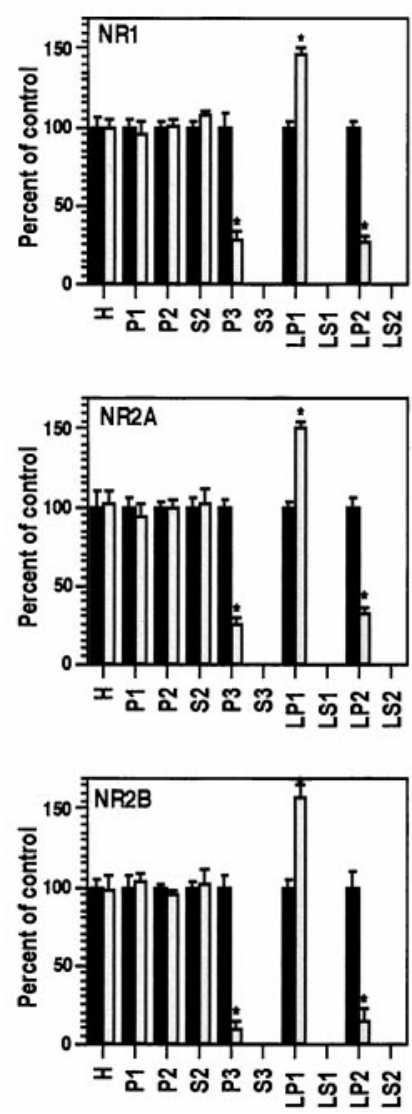

\section{SKF-82958+Genistein}
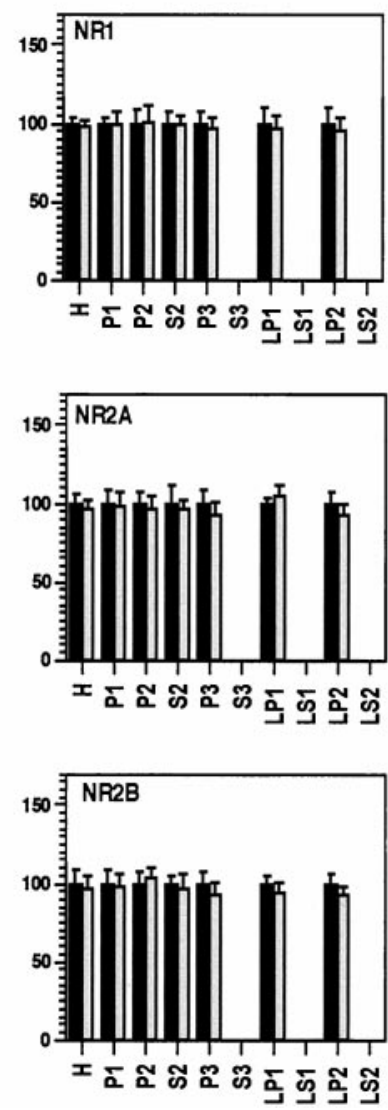

Figure 5. Densitometric quantification of NMDA receptor subunit NR1, NR2A, and NR2B proteins in striatal tissues that were treated with the dopamine D1 receptor agonist SKF-82958 (left panels) and with a combination of the dopamine D1 receptor agonist SKF-82958 and a protein tyrosine kinase inhibitor genistein (right panels). The exposed films from the experiments depicted in Figures $4 A$ and $10 A$ were scanned and analyzed as described in Materials and Methods. Values on the ordinate represent the relative levels of NR1, NR2A, and NR2B proteins given as a percentage of the control samples. Data are means \pm SEM obtained from three rats. Asterisks indicate significant differences between treatment and control samples $(p<0.05$, ANOVA). The alteration in the subcellular distribution of NR1, NR2A, and NR2B subunits produced by SKF-82958 was blocked by genistein.

the light membrane (P3) and synaptic vesicle-enriched (LP2) fractions was detected (Fig. 8B1,B2). This finding was particularly striking when compared with the marked enhancement of tyrosine phosphorylation of proteins other than the NR2A and NR2B subunits in the P3 fraction (Fig. 8A, lane 10).

\section{Blockade of the effects of dopamine D1 receptor activation on NMDA receptors by a protein tyrosine kinase inhibitor}

To examine the role of tyrosine phosphorylation in the subcellular redistribution of NMDA receptors after treatment with the dopamine D1 receptor agonist SKF-82958, we pretreated striatal tissues with the protein tyrosine kinase inhibitor genistein. Treatment of striatal tissues with genistein alone produced an apparent decrease in protein tyrosine phosphorylation, especially in the synaptosomal membrane fraction (Fig. 9A, $P Y, L P 1$ ). There was no alteration in the relative levels of NR1, NR2A, or NR2B in the subcellular compartments that were examined (Fig. 9A, Table
1). There was, however, an apparent decrease in the tyrosine phosphorylation of NR2A and NR2B in each of the subcellular fractions that contained these subunits (Fig. 9B1,B2).

In the striatal tissues that were treated with the dopamine D1 receptor agonist SKF-82958 in the presence of genistein, the changes that were observed in the subcellular distribution of NMDA subunits after treatment with the dopamine D1 receptor agonist alone were no longer apparent (Figs. 5, 10 $A$ ). The abundance of each of the NMDA subunits in the light membrane (P3), synaptosomal membrane (LP1), and synaptic vesicle-enriched (LP2) compartments was identical in control samples and in the samples that were treated with a combination of SKF-82958 and genistein (Fig. 10 $A$, Table 1). In addition, genistein blocked the increase in tyrosine phosphorylation of NR2A and NB2B in each subcellular compartment that was investigated (Fig. 10B1,B2, Table 2).

\section{DISCUSSION}

The NR1, NR2A, and NR2B subunits in the striatum are confined to biochemical fractions containing cellular membranes, particularly the synaptosomal membrane (LP1), synaptic vesicleenriched (LP2), and light membrane (P3) compartments. Tyrosine-phosphorylated NR2A and NR2B subunits are found only in the synaptosomal membrane fraction and not in the light membrane and synaptic vesicle-enriched fractions. The dopamine $\mathrm{D} 1$ receptor agonist produces a rapid alteration in the distribution of NR1, NR2A, and NR2B proteins, with a reduction in these subunits in the light membrane and synaptic vesicleenriched compartments and an increase in the synaptosomal membranes. These changes in subcellular distribution are accompanied by an increase in tyrosine phosphorylation of the NR2A and NR2B present in synaptosomal membranes. The alterations in the distribution and phosphorylation of NMDA receptors produced by SKF-82958 are abolished by a protein tyrosine kinase inhibitor and mimicked by a protein phosphatase inhibitor. These observations reveal the existence of a rapid dopaminedependent mechanism for intracellular trafficking of striatal NMDA receptors and reveal that these effects are mediated via a tyrosine kinase-dependent mechanism.

\section{Subcellular distribution of NMDA receptors and associated proteins in the striatum}

In the rat striatum, cortex, and cerebellum the NMDA subunits $\mathrm{NR} 1, \mathrm{NR} 2 \mathrm{~A}$, and NR2B are present in three membraneassociated compartments (LP1, LP2, and P3) and were undetected in cytosolic fractions. This is consistent with anatomical studies showing that NMDA receptor proteins are present both at postsynaptic sites and in intracellular locations, where they often are associated with membranous structures (Petralia et al., 1994). The LP1 fraction contains postsynaptic density, an organized cytoskeletal structure located within the postsynaptic neuron at sites of excitatory synapses that contain both NMDA and nonNMDA glutamate receptors, and a variety of other proteins involved in receptor anchoring, signaling, and modulation (Kennedy, 1993; Ziff, 1997). The LP2 contains synaptic vesicles and other vesicles that function as trafficking organelles for several membrane proteins, including neurotransmitter receptors (Sudhof, 1995; Takamori et al., 2000), whereas P3 contains cellular organelles that include endoplasmic reticulum, Golgi apparatus, and synaptic mitochondria (Schapira, 1998). The PSD-95, an integral component of the postsynaptic density, was highly 
Table 1. Quantitation of the relative amounts of NR1, NR2A, NR2B, PSD-95, $\alpha$-actinin-2, and NSF in various subcellular compartments of the striatum after treatment with pharmacologic agents

Percentage of control

\begin{tabular}{|c|c|c|c|c|c|c|c|c|c|c|c|}
\hline \multirow[b]{2}{*}{ Treatment } & \multirow[b]{2}{*}{ Proteins } & \multicolumn{10}{|c|}{ Percentage of control } \\
\hline & & $\mathrm{H}$ & $\mathrm{P} 1$ & $\mathrm{P} 2$ & $\mathrm{~S} 2$ & P3 & S3 & LP1 & LS1 & LP2 & LS2 \\
\hline P3 & $\mathrm{S} 3$ & & & & & & & & & & \\
\hline \multirow[t]{6}{*}{ SKF-82958 } & NR1 & $99 \pm 6$ & $95 \pm 8$ & $91 \pm 4$ & $94 \pm 3$ & $28 \pm 5$ & & $146 \pm 5$ & & $27 \pm 4$ & \\
\hline & NR2A & $102 \pm 8$ & $94 \pm 8$ & $92 \pm 6$ & $93 \pm 8$ & $25 \pm 4$ & & $150 \pm 4$ & & $32 \pm 4$ & \\
\hline & NR2B & $98 \pm 9$ & $103 \pm 6$ & $91 \pm 4$ & $92 \pm 9$ & $9 \pm 5$ & & $158 \pm 8$ & & $15 \pm 7$ & \\
\hline & PSD-95 & $106 \pm 4$ & $95 \pm 5$ & $98 \pm 5$ & & $99 \pm 5$ & & $103 \pm 5$ & & & \\
\hline & $\alpha$-Actinin-2 & $106 \pm 5$ & $102 \pm 4$ & $101 \pm 5$ & $108 \pm 6$ & $100 \pm 4$ & $109 \pm 6$ & $100 \pm 7$ & $109 \pm 8$ & $106 \pm 8$ & $93 \pm 8$ \\
\hline & NSF & $96 \pm 8$ & $98 \pm 7$ & $105 \pm 8$ & $104 \pm 9$ & $95 \pm 8$ & & $104 \pm 11$ & & $98 \pm 9$ & \\
\hline \multirow[t]{6}{*}{ SKF-38393 } & NR1 & $96 \pm 8$ & $95 \pm 8$ & $96 \pm 7$ & $101 \pm 6$ & $89 \pm 6$ & & $107 \pm 6$ & & $83 \pm 10$ & \\
\hline & NR2A & $96 \pm 7$ & $92 \pm 8$ & $97 \pm 8$ & $96 \pm 6$ & $95 \pm 5$ & & $105 \pm 7$ & & $94 \pm 8$ & \\
\hline & NR2B & $96 \pm 4$ & $95 \pm 5$ & $108 \pm 7$ & $107 \pm 5$ & $90 \pm 8$ & & $116 \pm 6$ & & $91 \pm 7$ & \\
\hline & PSD-95 & $103 \pm 7$ & $101 \pm 7$ & $96 \pm 5$ & & $105 \pm 7$ & & $103 \pm 5$ & & & \\
\hline & $\alpha$-Actinin-2 & $108 \pm 4$ & $101 \pm 4$ & $101 \pm 7$ & $98 \pm 4$ & $96 \pm 5$ & $102 \pm 3$ & $109 \pm 4$ & $103 \pm 4$ & $95 \pm 7$ & $102 \pm 6$ \\
\hline & NSF & $96 \pm 5$ & $105 \pm 4$ & $99 \pm 5$ & $96 \pm 7$ & $96 \pm 5$ & & $101 \pm 9$ & & $96 \pm 5$ & \\
\hline \multirow[t]{6}{*}{ Quinpirole } & NR1 & $101 \pm 4$ & $101 \pm 6$ & $104 \pm 6$ & $92 \pm 7$ & $111 \pm 7$ & & $98 \pm 9$ & & $106 \pm 8$ & \\
\hline & NR2A & $99 \pm 10$ & $96 \pm 9$ & $104 \pm 9$ & $104 \pm 6$ & $108 \pm 8$ & & $102 \pm 5$ & & $109 \pm 9$ & \\
\hline & NR2B & $95 \pm 4$ & $95 \pm 5$ & $100 \pm 8$ & $101 \pm 6$ & $98 \pm 6$ & & $105 \pm 7$ & & $98 \pm 4$ & \\
\hline & PSD-95 & $95 \pm 9$ & $93 \pm 5$ & $99 \pm 7$ & & $101 \pm 4$ & & $104 \pm 6$ & & & \\
\hline & $\alpha$-Actinin-2 & $97 \pm 6$ & $108 \pm 6$ & $100 \pm 4$ & $103 \pm 5$ & $107 \pm 4$ & $97 \pm 8$ & $94 \pm 4$ & $102 \pm 7$ & $106 \pm 5$ & $108 \pm 9$ \\
\hline & NSF & $104 \pm 6$ & $98 \pm 9$ & $99 \pm 8$ & $98 \pm 6$ & $102 \pm 5$ & & $100 \pm 4$ & & $103 \pm 5$ & \\
\hline \multirow[t]{6}{*}{ Pervanadate } & NR1 & $95 \pm 5$ & $99 \pm 7$ & $92 \pm 6$ & $92 \pm 3$ & $11 \pm 6$ & & $165 \pm 5$ & & $21 \pm 5$ & \\
\hline & NR2A & $104 \pm 5$ & $108 \pm 4$ & $93 \pm 5$ & $93 \pm 5$ & $6 \pm 5$ & & $142 \pm 4$ & & $17 \pm 6$ & \\
\hline & NR2B & $108 \pm 6$ & $102 \pm 7$ & $91 \pm 6$ & $91 \pm 4$ & $2 \pm 4$ & & $179 \pm 5$ & & $11 \pm 5$ & \\
\hline & PSD-95 & $98 \pm 4$ & $106 \pm 10$ & $98 \pm 8$ & & $107 \pm 5$ & & $104 \pm 7$ & & & \\
\hline & $\alpha$-Actinin-2 & $99 \pm 6$ & $106 \pm 10$ & $98 \pm 9$ & $98 \pm 6$ & $106 \pm 8$ & $102 \pm 8$ & $97 \pm 9$ & $102 \pm 7$ & $103 \pm 7$ & $98 \pm 3$ \\
\hline & NSF & $99 \pm 7$ & $96 \pm 9$ & $98 \pm 8$ & $102 \pm 9$ & $101 \pm 6$ & & $99 \pm 9$ & & $105 \pm 7$ & \\
\hline \multirow[t]{6}{*}{ Genistein } & NR1 & $96 \pm 6$ & $103 \pm 6$ & $108 \pm 4$ & $104 \pm 7$ & $94 \pm 9$ & & $92 \pm 6$ & & $106 \pm 9$ & \\
\hline & NR2A & $100 \pm 6$ & $95 \pm 10$ & $100 \pm 7$ & $102 \pm 8$ & $102 \pm 7$ & & $101 \pm 5$ & & $98 \pm 9$ & \\
\hline & NR2B & $106 \pm 7$ & $105 \pm 7$ & $103 \pm 6$ & $100 \pm 7$ & $102 \pm 5$ & & $90 \pm 4$ & & $92 \pm 8$ & \\
\hline & PSD-95 & $96 \pm 5$ & $95 \pm 5$ & $97 \pm 5$ & & $108 \pm 6$ & & $101 \pm 8$ & & & \\
\hline & $\alpha$-Actinin-2 & $95 \pm 5$ & $105 \pm 9$ & $100 \pm 6$ & $97 \pm 6$ & $96 \pm 6$ & $96 \pm 6$ & $98 \pm 5$ & $105 \pm 5$ & $103 \pm 6$ & $102 \pm 9$ \\
\hline & NSF & $102 \pm 6$ & $100 \pm 7$ & $94 \pm 7$ & $98 \pm 7$ & $97 \pm 9$ & & $98 \pm 6$ & & $103 \pm 10$ & \\
\hline \multirow[t]{6}{*}{ SKF-82958 + Genistein } & NR1 & $98 \pm 4$ & $100 \pm 7$ & $101 \pm 10$ & $99 \pm 6$ & $96 \pm 7$ & & $93 \pm 6$ & & $95 \pm 7$ & \\
\hline & NR2A & $96 \pm 6$ & $98 \pm 10$ & $101 \pm 9$ & $96 \pm 6$ & $93 \pm 8$ & & $105 \pm 6$ & & $94 \pm 8$ & \\
\hline & NR2B & $97 \pm 8$ & $98 \pm 8$ & $103 \pm 7$ & $96 \pm 10$ & $92 \pm 9$ & & $94 \pm 9$ & & $92 \pm 6$ & \\
\hline & PSD-95 & $94 \pm 3$ & $99 \pm 4$ & $101 \pm 7$ & & $104 \pm 8$ & & $102 \pm 4$ & & & \\
\hline & $\alpha$-Actinin-2 & $92 \pm 5$ & $94 \pm 5$ & $99 \pm 5$ & $96 \pm 4$ & $92 \pm 6$ & $94 \pm 9$ & $105 \pm 3$ & $99 \pm 9$ & $94 \pm 5$ & $101 \pm 7$ \\
\hline & NSF & $96 \pm 6$ & $95 \pm 4$ & $99 \pm 5$ & $107 \pm 7$ & $101 \pm 4$ & & $102 \pm 5$ & & $99 \pm 4$ & \\
\hline
\end{tabular}

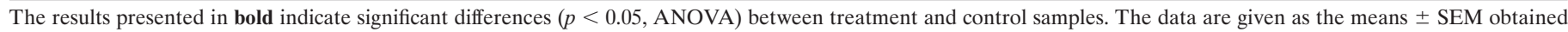
from three rats.

concentrated in the synaptosomal membrane (LP1) fraction but was absent in the cytosolic and synaptic vesicle-enriched (LP2) compartments. In contrast, $\alpha$-actinin- 2 was found in both membrane-associated and cytosolic compartments. Both proteins are known to link NMDA receptors physically and functionally to the postsynaptic density (Kornau et al., 1995; Wyszynski et al., 1998), although our recent report revealed that only a minor but perhaps functionally significant fraction of the $\alpha$-actinin-2 present in rat striatum is bound directly to NMDA receptors (Dunah et al., 2000b).

\section{Trafficking of NMDA receptors from intracellular compartments to the synaptic membrane}

Mounting evidence suggests that the activities of the striatum are regulated by complex interactions between dopamine and NMDA receptors (Di Chiara et al., 1994; Cepeda and Levine, 1998; Schoffelmeer et al., 2000). We found that the dopamine D1 receptor agonist SKF-82958 produced a rapid redistribution of NMDA subunits among subcellular compartments of the striatum. This process of receptor redistribution appears to be specific 
Table 2. Quantitation of tyrosine-phosphorylated NMDA receptor subunits NR2A and NR2B in striatal subcellular compartments after treatment with pharmacologic agents

\begin{tabular}{|c|c|c|c|c|c|c|c|c|c|c|c|}
\hline \multirow[b]{2}{*}{ Treatment } & \multirow[b]{2}{*}{ Subunits } & \multicolumn{10}{|c|}{ Percentage of control } \\
\hline & & $\mathrm{H}$ & $\mathrm{P} 1$ & $\mathrm{P} 2$ & $\mathrm{~S} 2$ & P3 & S3 & LP1 & LS1 & LP2 & LS2 \\
\hline \multirow[t]{2}{*}{ SKF-82958 } & NR2A & $142 \pm 7$ & $146 \pm 9$ & $141 \pm 6$ & & & & $154 \pm 5$ & & & \\
\hline & NR2B & $147 \pm 10$ & $142 \pm 6$ & $153 \pm 6$ & & & & $161 \pm 6$ & & & \\
\hline \multirow[t]{2}{*}{ SKF-38393 } & NR2A & $99 \pm 11$ & $106 \pm 10$ & $98 \pm 11$ & & & & $104 \pm 5$ & & & \\
\hline & NR2B & $104 \pm 8$ & $102 \pm 8$ & $109 \pm 7$ & & & & $107 \pm 7$ & & & \\
\hline \multirow[t]{2}{*}{ Quinpirole } & NR2A & $96 \pm 6$ & $101 \pm 9$ & $104 \pm 5$ & & & & $107 \pm 6$ & & & \\
\hline & NR2B & $98 \pm 7$ & $105 \pm 4$ & $104 \pm 9$ & & & & $97 \pm 5$ & & & \\
\hline \multirow[t]{2}{*}{ Pervanadate } & NR2A & $174 \pm 6$ & $176 \pm 8$ & $171 \pm 8$ & & & & $183 \pm 7$ & & & \\
\hline & NR2B & $184 \pm 8$ & $187 \pm 8$ & $171 \pm 10$ & & & & $181 \pm 5$ & & & \\
\hline \multirow[t]{2}{*}{ Genistein } & NR2A & $52 \pm 8$ & $51 \pm 6$ & $49 \pm 5$ & & & & $44 \pm 4$ & & & \\
\hline & NR2B & $53 \pm 6$ & $51 \pm 8$ & $52 \pm 6$ & & & & $50 \pm 10$ & & & \\
\hline \multirow[t]{2}{*}{ SKF-82958 + Genistein } & NR2A & $66 \pm 10$ & $64 \pm 7$ & $62 \pm 6$ & & & & $67 \pm 6$ & & & \\
\hline & NR2B & $75 \pm 8$ & $73 \pm 7$ & $68 \pm 6$ & & & & $72 \pm 8$ & & & \\
\hline
\end{tabular}

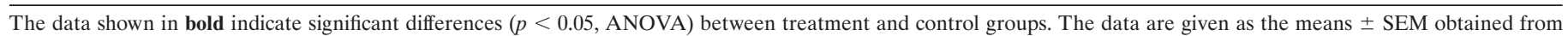
three rats.

for the NMDA subunits, because the AMPA receptor subunits GluR1 and GluR2/3, as well as PSD-95 and $\alpha$-actinin-2, proteins that interact with NMDA receptors (Kornau et al., 1995; Wyszynski et al., 1998), and NSF, a protein that binds to AMPA receptors (Nishimune et al., 1998; Osten and Ziff, 1999), were not altered. In addition, the effect of the dopamine D1 agonist on NMDA receptor distribution and phosphorylation was not observed in either the cerebral cortex or the cerebellum. This may result from the existence of a lower density of D1 dopamine receptors in the cortex and the virtual lack of expression of these receptors in the cerebellum (De Keyser, 1993; Sealfon and O1anow, 2000). However, it is also possible that there are unique anatomical and structural properties of striatal neurons that are required for this interaction of glutamatergic and dopaminergic transmission (Cepeda and Levine, 1998; Schoffelmeer et al., 2000).

We propose that the alterations in subcellular distribution reflect the dopamine D1 receptor-induced trafficking of NR1, NR2A, and NR2B proteins from the light membrane and synaptic vesicle-enriched compartments to the synaptic membranes (Fig. 11). Because we analyzed only the total receptor proteins in each compartment and did not follow individual subunits directly over time, the involvement of a more complex mechanism of subcellular redistribution of receptors cannot be excluded. For instance, the observed changes could arise from enhanced degradation of the NMDA receptors in the light membrane and synaptic vesicle-enriched compartments, together with the insertion of receptors into the synaptic membranes from other sources that are not identifiable by the present experimental approach.

Recent studies have provided ample evidence that redistribution is an important mechanism for regulating AMPA receptors. Both synaptic activity and the increased activity of calcium calmodulin-dependent protein kinase II can rapidly induce the trafficking of GFP-tagged GluR1 receptors to the postsynaptic membrane (Shi et al., 1999; Hayashi et al., 2000). The recruitment of GluR1 receptors to the postsynaptic density has been found to increase AMPA receptor-mediated synaptic transmission in longterm potentiation (Hayashi et al., 2000). Similarly, insulin causes $\mathrm{GABA}_{\mathrm{A}}$ receptors to translocate rapidly from intracellular compartments to the plasma membrane, an effect probably mediated by phosphorylation of the receptors at tyrosine residues (Wan et al., 1997). Use-dependent downregulation of NMDA receptors appears to involve a clathrin-mediated process of endocytosis (Vissel et al., 2001), and activators of protein kinase C, including insulin, recruit new NMDA receptors to the cell surface via a process involving vesicular trafficking (Lan et al., 2001; Scott et al., 2001; Skeberdis et al., 2001).

\section{Striatal NMDA receptor trafficking requires tyrosine phosphorylation}

Our findings directly implicate tyrosine phosphorylation in the subcellular redistribution of striatal NMDA receptors. Consistent with previous reports (Moon et al., 1994; Lau et al., 1995; Dunah et al., 1998), the NR2A and NR2B subunits, but not NR1, in striatum were found to be tyrosine-phosphorylated. After analysis of specific subcellular compartments, tyrosinephosphorylated NR2A and NR2B subunits in the synaptosomal membrane, but not in the light membrane and synaptic vesicleenriched fractions, were detected. Treatment with the dopamine D1 agonist SKF-82958 produced an increase in tyrosinephosphorylated NR2A and NR2B in the synaptosomal membrane fraction. This effect was mimicked by pervanadate, a nonspecific inhibitor of protein phosphatases, which also increased the tyrosine phosphorylation of many membrane-associated proteins. Interestingly, even after a pharmacologic blockade of protein phosphatases, tyrosine phosphorylation of NR2A or NR2B in the light membrane or synaptic vesicle-enriched fractions was not observed. The effects of SKF-82958 on both subcellular distribution and tyrosine phosphorylation of NR2A and NR2B were blocked by genistein, a protein tyrosine kinase inhibitor.

We suggest, therefore, that tyrosine phosphorylation of the pool of NR2A and NR2B receptors in the light membrane and 


\section{QUINPIROLE}
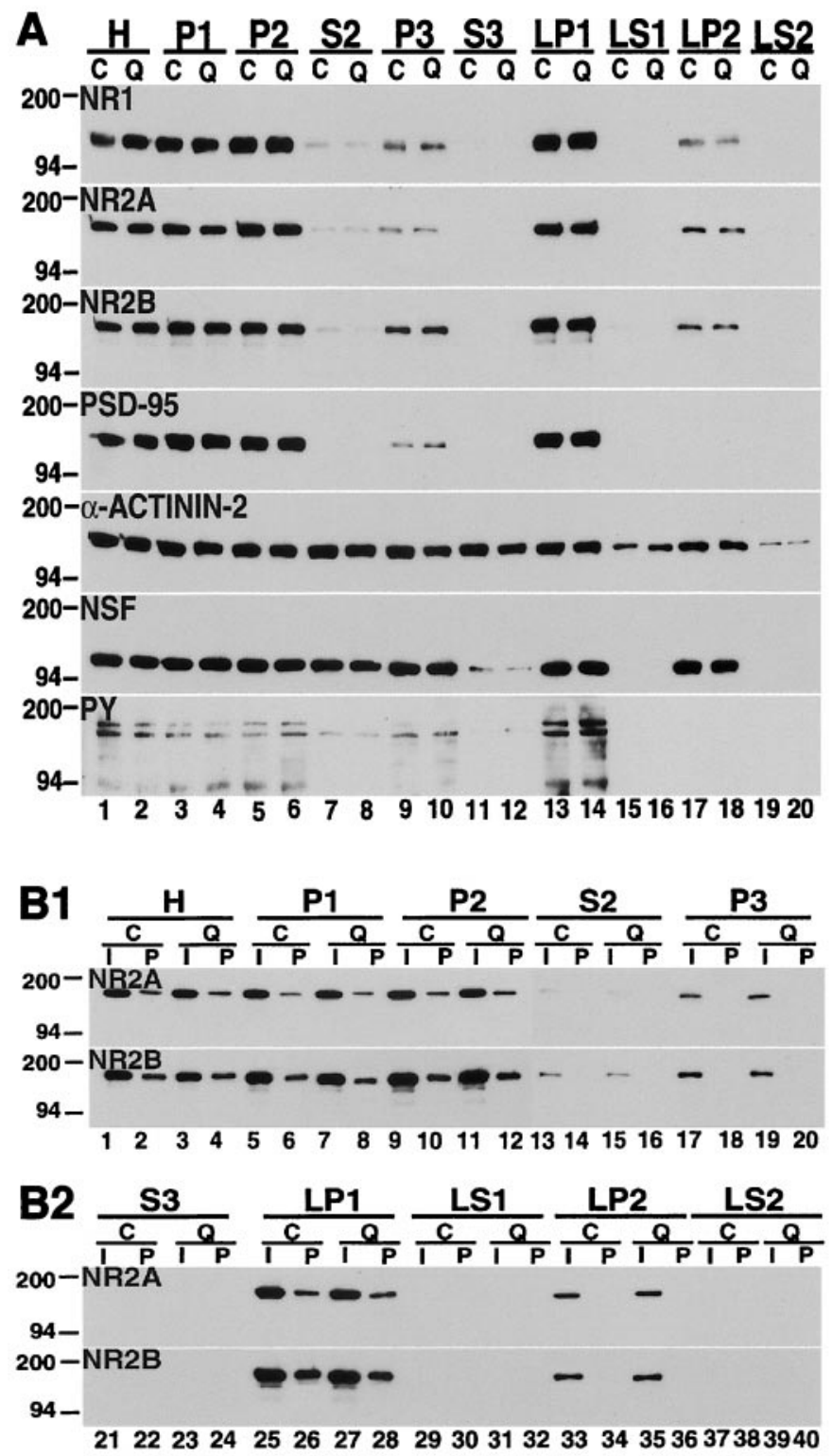

Figure 6. The dopamine D2 receptor agonist quinpirole does not alter the subcellular distribution and tyrosine phosphorylation of striatal NMDA receptors. $A$, Subcellular distribution. Samples from tissues that were incubated for $10 \mathrm{~min}$ under control conditions $(C)$ or with $100 \mu \mathrm{M}$ quinpirole (a dopamine D2 receptor agonist; $Q$ ) were separated into subcellular fractions and subjected to electrophoresis on SDSpolyacrylamide gels. The blots were probed with NR1, NR2A, NR2B, PSD-95, $\alpha$-actinin-2, NSF, and anti-phosphotyrosine $(P Y)$ antibodies. There were no significant differences in the subcellular distribution of the analyzed proteins between control and quinpirole-treated samples. B1, $B 2$, Tyrosine phosphorylation. Striatal tissues from control $(C)$ and quinpirole-treated $(Q)$ samples were solubilized and precipitated with anti-phosphotyrosine antibody. The inputs $(I)$ and pellets $(P)$ are indicated across the top of the figure. The resulting blots were immunoblotted for the NR2A and NR2B subunits. Quinpirole had no apparent effect on the tyrosine phosphorylation of NR2A and NR2B subunits.

synaptic vesicle-enriched fractions functions as a trigger for the redistribution of these subunits from intracellular compartments to the synaptosomal membrane. This phenomenon would account for the rapidity of subcellular redistribution of the recep-
AMPA RECEPTORS: SKF-82958
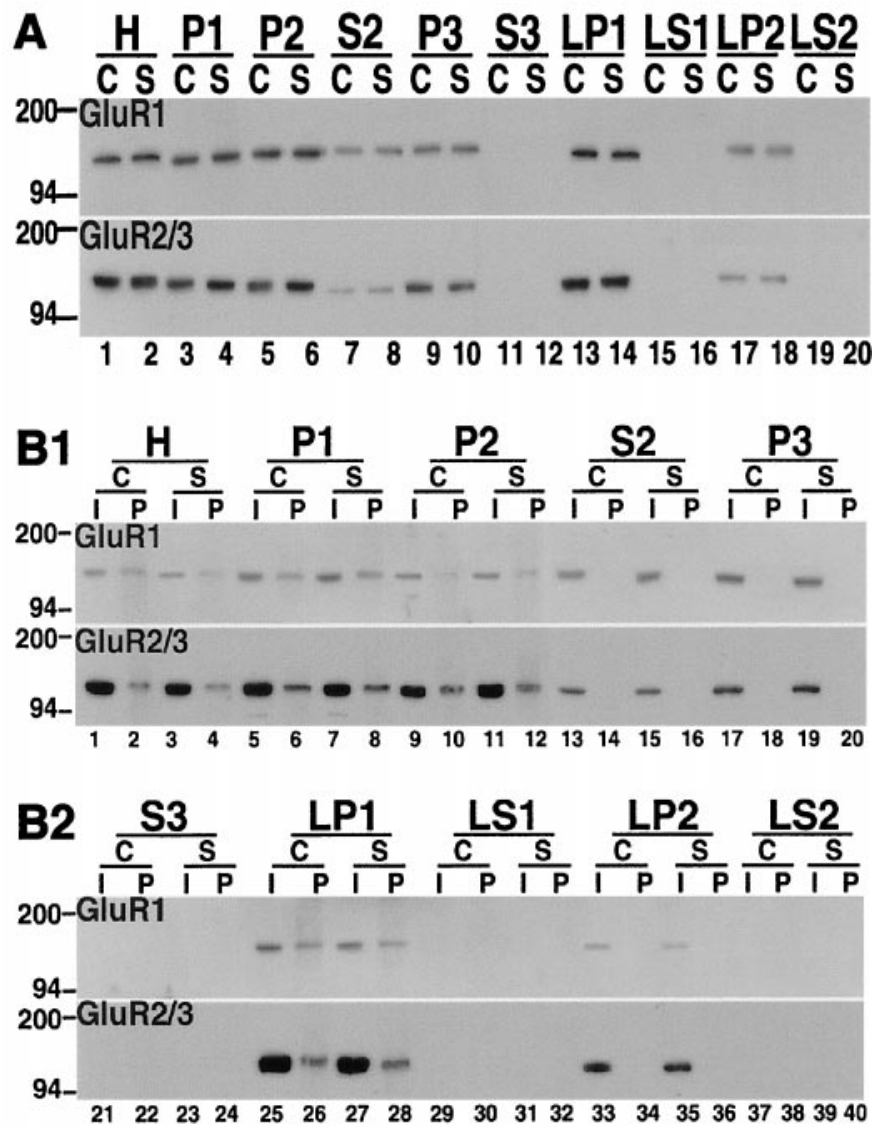

Figure 7. The dopamine D1 receptor agonist SKF-82958 had no effect on the subcellular distribution and tyrosine phosphorylation of striatal AMPA receptors. $A$, Subcellular distribution. Fractionated striatal tissues that were incubated for $10 \mathrm{~min}$ under control conditions $(C)$ or with 50 $\mu \mathrm{M}$ SKF-82958 $(S)$ were resolved by SDS-PAGE, and the blots were probed with antibodies specific for GluR1 and GluR2/3. SKF-82958 had no apparent effect on the subcellular distribution of GluR1 and GluR2/3 subunits. B1, B2, Tyrosine phosphorylation. The fractionated striatal samples were precipitated with anti-phosphotyrosine antibody and immunoblotted for GluR1 and GluR2/3. The inputs $(I)$ and pellets $(P)$ are indicated across the top of the figure. SKF-82958 produced no changes in the tyrosine phosphorylation of GluR1 or GluR2/3.

tors and the inability to detect tyrosine-phosphorylated NR2A and NR2B in the light membrane and synaptic vesicle-enriched fractions. The inhibition of protein phosphatases with orthovanadate triggers redistribution, suggesting the existence of a tonically active phosphatase activity. Interestingly, genistein can block the effect of dopamine D1 receptor activation but does not alter the basal distribution of the receptor subunits in the $10 \mathrm{~min}$ time period that was studied, suggesting that constitutive trafficking of subunits to the synaptosomal membrane is either a much slower process or uses a different tyrosine kinase-independent mechanism.

The regulatory steps between the activation of dopamine D1 receptors and the tyrosine phosphorylation of NR2A and NR2B subunits are understood incompletely. In other systems, however, members of the src family of protein tyrosine kinases, in particular the fyn kinases, have been shown to phosphorylate NMDA subunits (Gurd, 1985; Moon et al., 1994; Suzuki and OkumuraNoji, 1995), and this resulted in increased channel activity of the receptors (Köhr and Seeburg, 1996); fyn kinase knock-out mice 


\section{PERVANADATE}
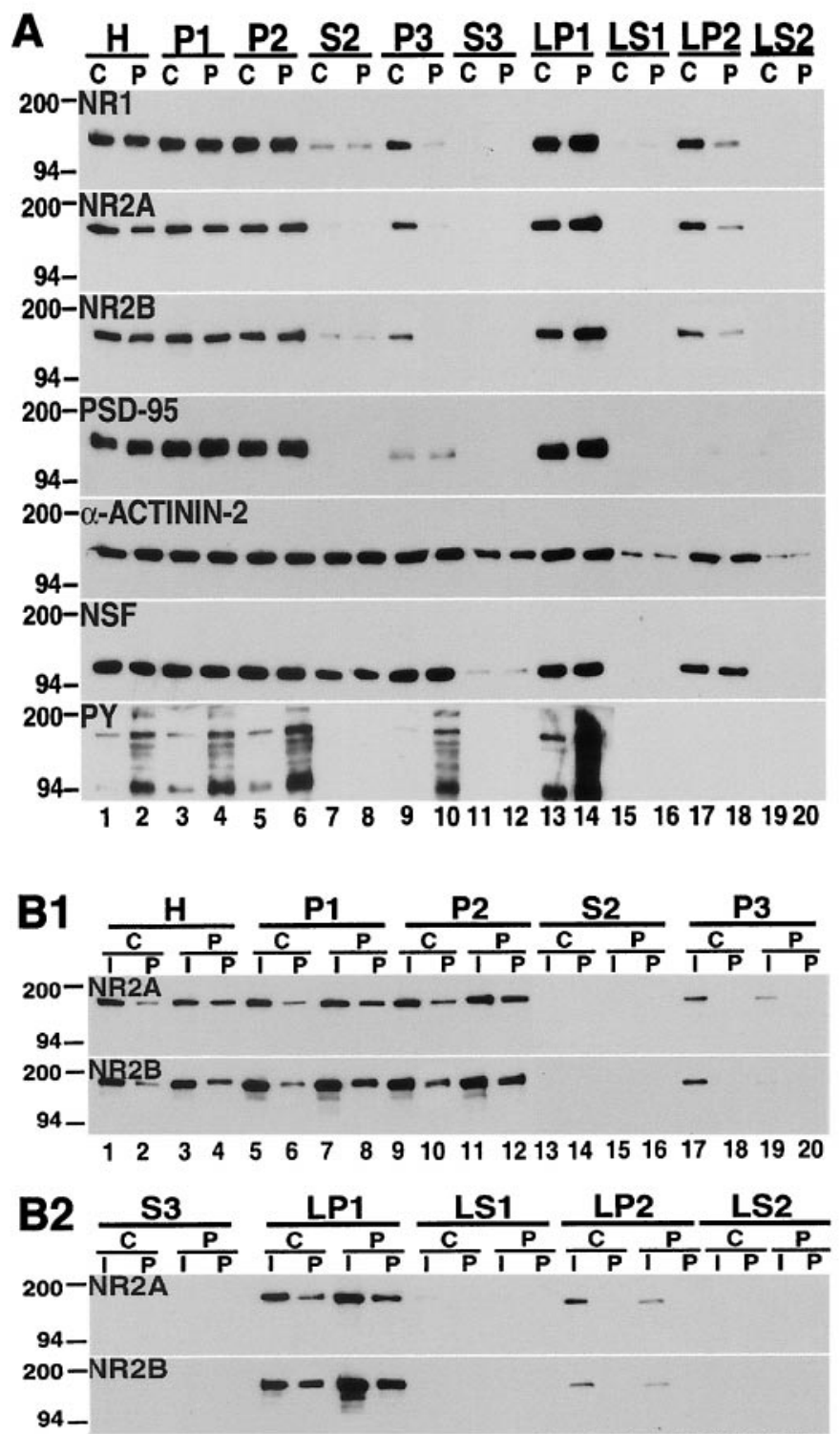

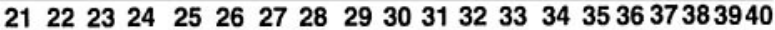

Figure 8. The protein phosphatase inhibitor pervanadate induces subcellular redistribution and an increase in tyrosine phosphorylation of striatal NMDA receptors. $A$, Subcellular distribution. Striatal samples from tissues that were incubated for $10 \mathrm{~min}$ under control conditions $(C)$ or with $200 \mu \mathrm{M}$ pervanadate $(P)$ were fractionated and resolved on SDS-PAGE gels. The blots were probed with NR1, NR2A, NR2B, PSD-95, $\alpha$-actinin, NSF, and anti-phosphotyrosine $(P Y)$ antibodies. Similar to the effects produced by SKF-82958, pervanadate reduced the levels of NR1, NR2A, and NR2B in P3 (lane 10) and LP2 (lane 18); it increased the levels of these NMDA subunits in LP1 (lane 14) and markedly increased phosphotyrosine proteins $(P Y)$. $B 1, B 2$, Tyrosine phosphorylation. Samples from the subcellular-fractionated control $(C)$ and pervanadate-treated $(P)$ striatal tissues were immunoprecipitated with anti-phosphotyrosine antibody. The inputs $(I)$ and pellets $(P)$ were electrophoresed and probed for NR2A and NR2B subunits. Tyrosine phosphorylation of NR2A and NR2B was increased in H (lane 4), P1 (lane 8), P2 (lane 12), and LP1 (lane 28).

have been reported to be deficient in certain forms of long-term potentiation (Grant et al., 1992). The striking increase in NR2A and NR2B tyrosine phosphorylation with pervanadate suggests tonic activity of a protein phosphatase in the striatum. Potential

\section{GENISTEIN}
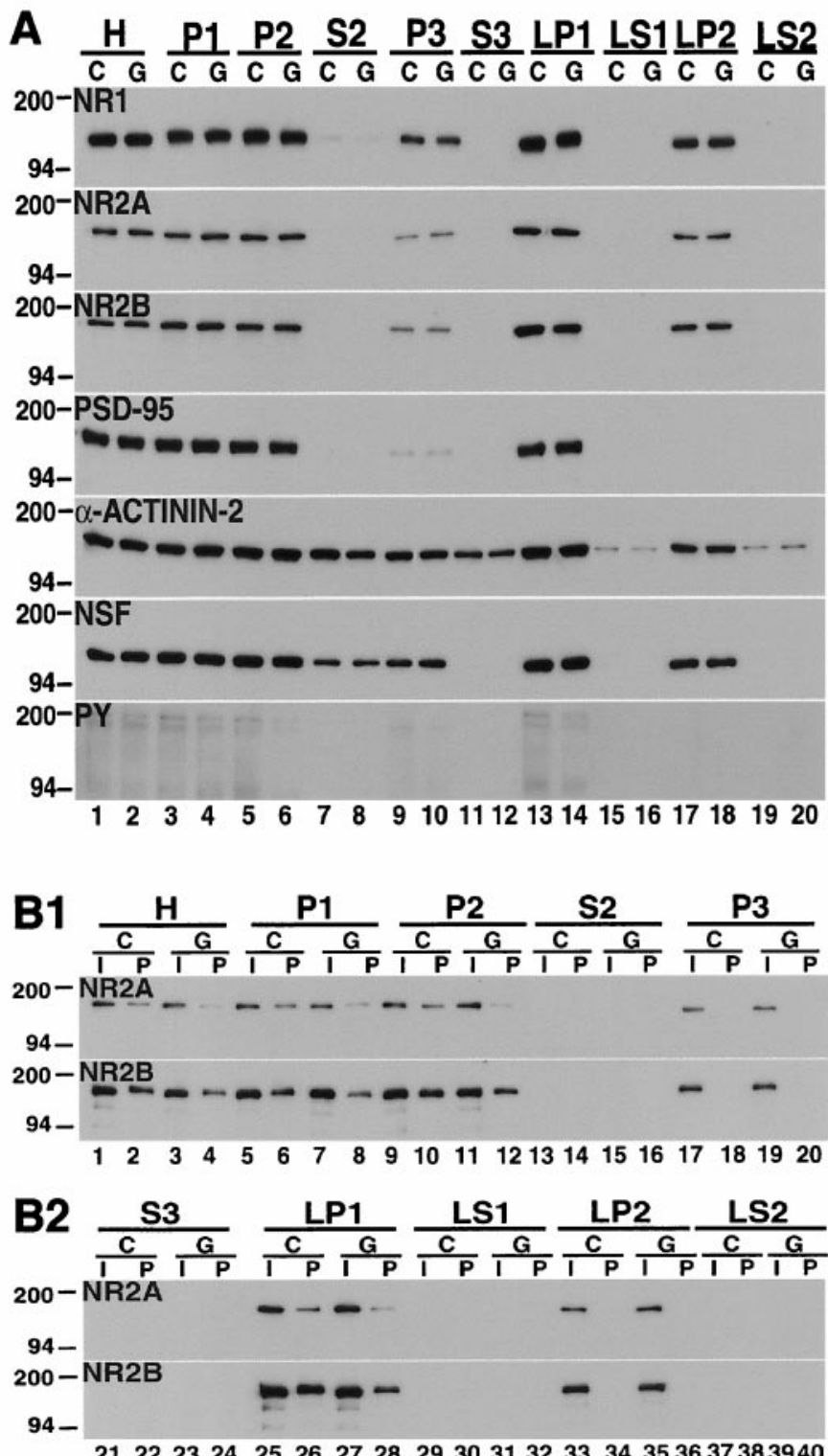

Figure 9. The protein tyrosine kinase inhibitor genistein does not change the subcellular distribution of striatal NMDA receptors but decreases the tyrosine phosphorylation of NR2A and NR2B. A, Subcellular distribution. Fractions from striatal tissues that were incubated for $10 \mathrm{~min}$ under control conditions $(C)$ or with $100 \mu \mathrm{M}$ genistein $(G)$ were electrophoresed on SDS-polyacrylamide gels, and the blots were probed with NR1, NR2A, NR2B, PSD-95, $\alpha$-actinin-2, NSF, and anti-phosphotyrosine $(P Y)$ antibodies. The subcellular localizations of NMDA receptor subunits and the other proteins that were studied were not changed by genistein, but there were reductions in total phosphotyrosine proteins $(P Y) . B 1, B 2$, Tyrosine phosphorylation. The fractionated samples from control $(C)$ and genistein-treated $(G)$ striatal tissues were immunoprecipitated by using anti-phosphotyrosine antibody and were immunoblotted with anti-NR2A and anti-NR2B antibodies. The inputs $(I)$ and pellets $(P)$ are indicated across the top of the figure. Genistein decreased the tyrosine phosphorylation of NR2A and NR2B in H (lane 4), P1 (lane 8), P2 (lane 12), and LP1 (lane 28).

candidates for this role are the striatal-enriched phosphatases (STEP), which are abundant in striatal neurons and are found in association with NMDA receptor subunits (Boulanger et al., 1995). 


\section{SKF-82958+GENISTEIN}
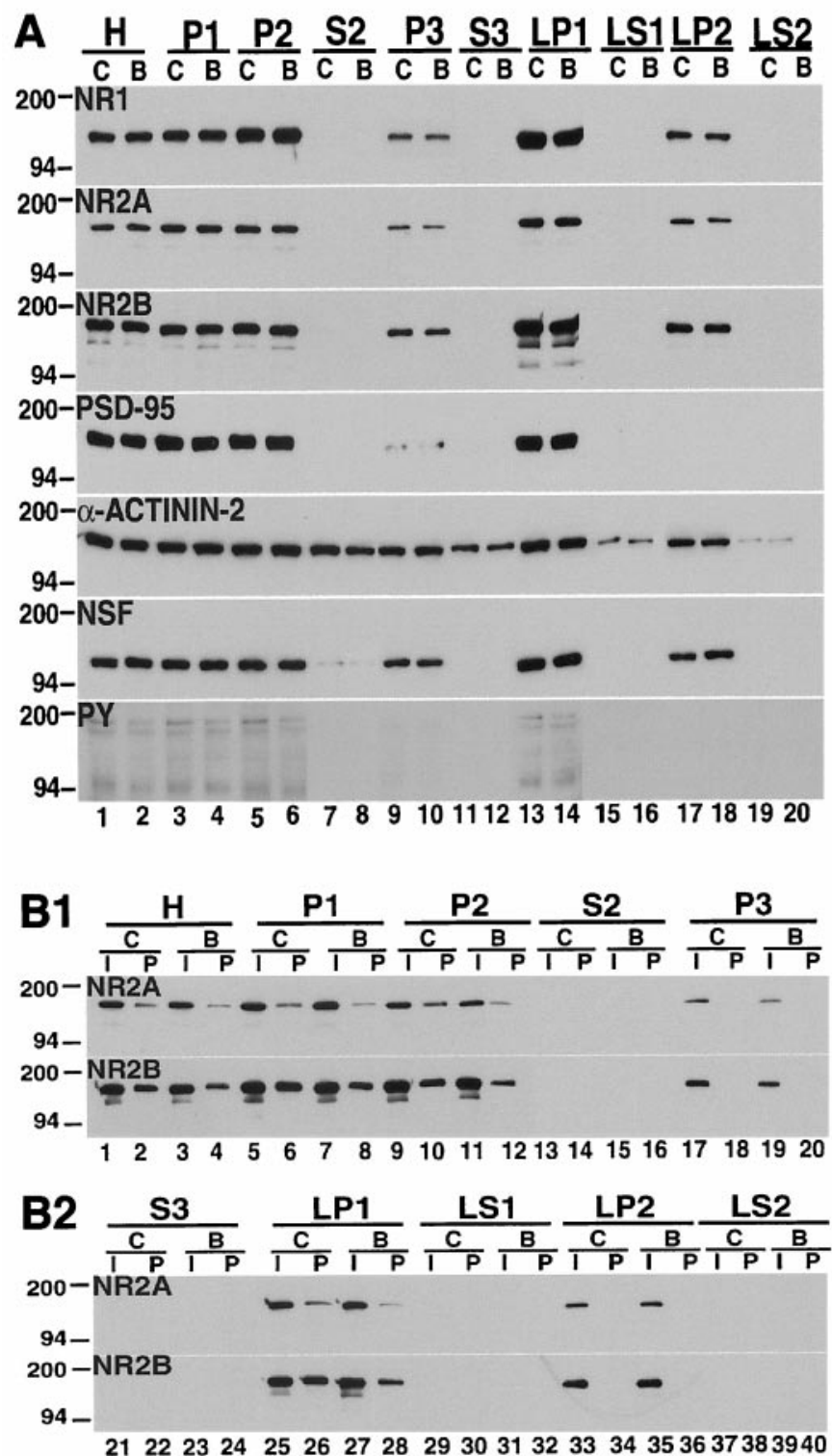

Figure 10. The dopamine D1 receptor agonist-induced alterations in subcellular distribution and tyrosine phosphorylation of striatal NMDA receptors are inhibited by the protein tyrosine kinase inhibitor genistein. $A$, Subcellular distribution. Samples from tissues that were incubated for 10 min under control conditions $(C)$ or with $50 \mu \mathrm{M}$ SKF-82958 and 100 $\mu \mathrm{M}$ genistein $(B)$ were subjected to subcellular fractionation. The proteins were separated on SDS-PAGE, and the blots were probed with antibodies against NR1, NR2A, NR2B, PSD-95, $\alpha$-actinin-2, NSF, and phosphotyrosine proteins $(P Y)$. In the presence of genistein, SKF-82958 produced no alteration in the distribution of NMDA receptor subunits. $B 1, B 2$, Tyrosine phosphorylation. Solubilized control $(C)$ and treated samples $(B)$ were immunoprecipitated with anti-phosphotyrosine antibody, and the blots were probed with NR2A and NR2B antibodies. The inputs $(I)$ and pellets $(P)$ are indicated across the top of the figure. Genistein inhibited the increase in tyrosine phosphorylation of NR2A and NR2B produced by the dopamine D1 receptor agonist SKF-82958.

There is evidence for a dopamine-regulated phosphorylation of the NR1 subunit at serine residues regulated by the phosphoprotein DARPP-32 (dopamine and cAMP-regulated phosphoprotein; Snyder et al., 1998). Phosphorylation at serine ${ }^{890}$, but not at serine $^{896}$ or serine ${ }^{897}$, produced a redistribution of NR1 recep-

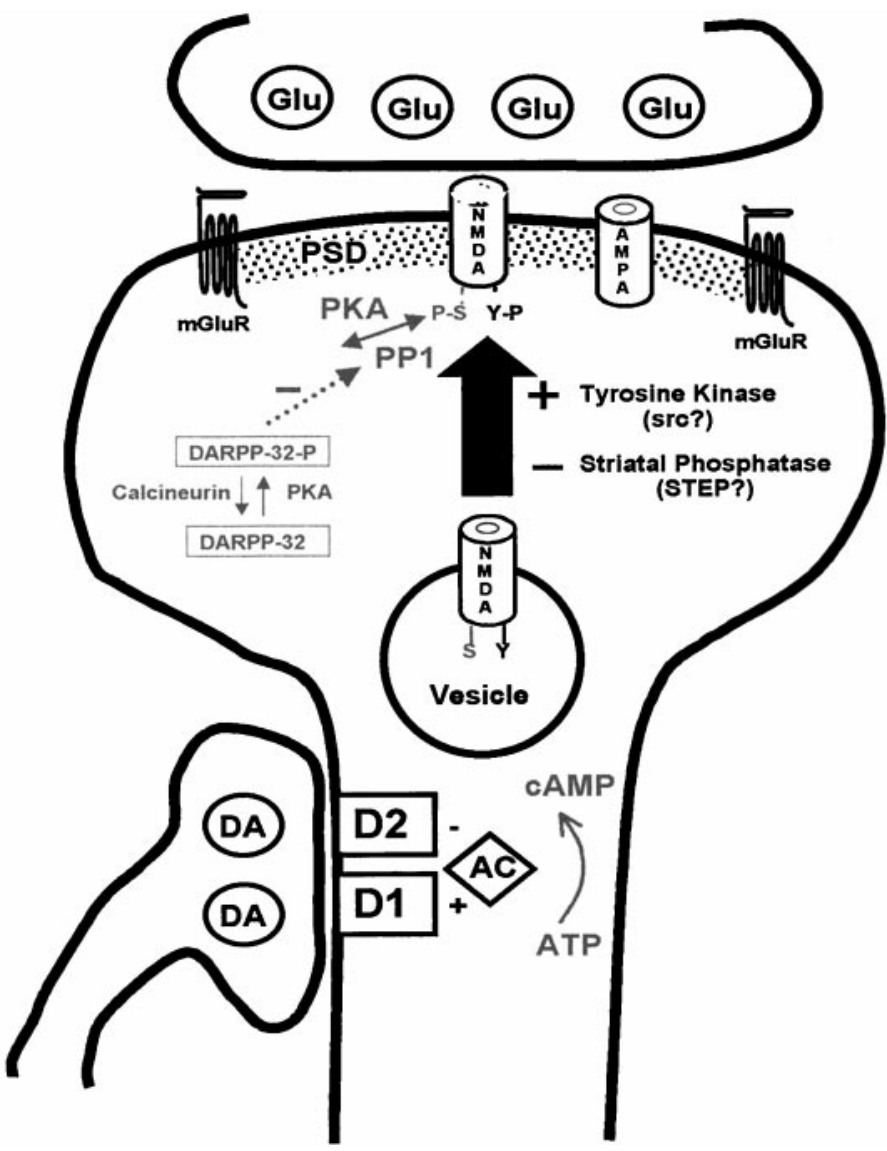

Figure 11. Model for the trafficking of NMDA receptors at the corticostriatal synapse. Illustrated is a dendritic spine of a striatal projection neuron receiving input from a cortical axon, using glutamate as a transmitter $(G l u)$ at the head of the spine, and from a nigrostriatal axon, using dopamine $(D A)$ as a transmitter and forming a synapse on the shaft of the spine. The effects of glutamate are mediated by NMDA, AMPA, and metabotropic glutamate receptors $(m G l u R)$. These are linked to each other and to additional signaling molecules via the proteins of the postsynaptic density $(P S D)$. Dopaminergic inputs are mediated by the dopamine D1 and D2 receptors. These receptors have reciprocal effects on the formation of cAMP by adenylyl cyclase $(A C)$, but most striatal neurons express a preponderance of a single dopamine receptor type, depending on whether they contribute to the direct or indirect pathways. In addition to the NMDA receptors that are present at the excitatory synapse, our data suggest that there is a pool of assembled receptors within intracellular vesicular compartments. The vesicle-associated receptors are characterized by the absence of tyrosine $(Y)$ phosphorylation of the NR2A and NR2B subunits. Activation of dopamine D1 receptors leads (via mechanisms that are not well defined) to tyrosine phosphorylation of the vesicular NMDA receptor subunits by a tyrosine kinase [perhaps a member of the src family reported to phosphorylate NMDA subunits at tyrosine residues (Suzuki and Okumura-Noji, 1995)] and insertion of the receptors into the synaptic membrane. There is also a tonically active tyrosine phosphatase, which may be a member of the STEP family. The diagram also illustrates the serine $(S)$ phosphorylation of the NR1 subunit, which is regulated both by the direct action of CAMP on protein kinase A $(P K A)$ as well as by the DARPP-32 pathway; phosphorylation of DARPP-32 by PKA inhibits the dephosphorylation of NR1 by protein phosphatase-1 (PP-1; Snyder et al., 1998). Although protein kinase $\mathrm{C}$ has been reported to modulate the trafficking of NMDA receptors (Lan et al., 2001), the precise role of cAMP in the phosphorylation of NMDA subunits at tyrosine residues is not known. At present it is also uncertain whether serine phosphorylation plays a role in the trafficking of NMDA receptors at the corticostriatal synapse. 
tors from intracellular sites to the cell surface (Tingley et al., 1997). Thus, serine phosphorylation of the NR1 subunit in these receptor complexes may have a role in the trafficking of striatal NMDA receptors, but the ability of genistein to block receptor redistribution suggests that tyrosine phosphorylation is essential to this phenomenon.

\section{NMDA receptor trafficking and parkinsonism}

The present findings complement earlier studies of dopaminedependent modifications of NMDA receptors from our laboratory and others (Oh et al., 1998; Dunah et al., 2000a). In a previous study we analyzed the biochemical properties of striatal NMDA receptors in a rat model of unilateral 6-OHDA depletion. At $14 \mathrm{~d}$ postlesion we found significant reductions in NR1 and NR2B in the synaptosomal membranes, and treatment with levodopa for $21 \mathrm{~d}$ normalized both subunits (Dunah et al., 2000a). Although this in vivo study was performed over a longer time period, both the magnitude and direction of subcellular distribution of NMDA receptors are comparable with the results that have been described in the present study. Dopamine-dependent alterations in NMDA subunits, particularly the increased association of these receptors with corticostriatal synapses, may underlie the adverse motor effects that have been observed in patients with Parkinson's disease treated with dopaminergic drugs, which are the primary sources of ongoing disability in this neurodegenerative disease. The development of approaches targeted at modifying the trafficking of NMDA receptors in the striatum may prove to be useful in the treatment of Parkinson's disease.

\section{REFERENCES}

Barinaga M (1993) Secrets of secretion revealed. Science 260:487-489. Bennett MK, Calakos N, Scheller RH (1992) Syntaxin: a synaptic protein implicated in docking of synaptic vesicles at presynaptic active zones. Science 257:255-259.

Blanchet PJ, Papa SM, Metman LV, Mouradian MM, Chase TN (1997) Modulation of levodopa-induced motor response complications by NMDA antagonists in Parkinson's disease. Neurosci Biobehav Rev 21:447-453.

Boulanger LM, Lombroso PJ, Raghunathan A, During MJ, Wahle P, Naegele JR (1995) Cellular and molecular characterization of a brainenriched protein tyrosine phosphatase. J Neurosci 15:1532-1544.

Cepeda C, Levine MS (1998) Dopamine and $N$-methyl-D-aspartate receptor interactions in the neostriatum. Dev Neurosci 20:1-18.

Chase TN, Oh JD, Blanchet PJ (1998) Neostriatal mechanisms in Parkinson's disease. Neurology 51:S30-S35.

Chen C, Leonard JP (1996) Protein tyrosine kinase-mediated potentiation of currents from cloned NMDA receptors. J Neurochem 67:194-200.

David V, Hochstenbach F, Rajagopalan S, Brenner MB (1993) Interaction with newly synthesized and retained proteins in the endoplasmic reticulum suggests a chaperone function for human integral membrane protein IP90 (calnexin). J Biol Chem 268:9585-9592.

De Keyser J (1993) Subtypes and localization of dopamine receptors in human brain. Neurochem Int 22:83-93.

Devoto SH, Barnstable CJ (1987) Cellular and molecular biology of hormone- and neurotransmitter-containing secretory vesicles. Ann NY Acad Sci 493:1-590.

Di Chiara G, Morelli M, Consolo S (1994) Modulatory functions of neurotransmitters in the striatum: ACh/dopamine/NMDA interactions. Trends Neurosci 17:228-233.

Dingledine R, Borges K, Bowie D, Traynelis SF (1999) The glutamate receptor ion channels. Pharmacol Rev 51:7-61.

Dunah AW, Yasuda RP, Luo J, Wang Y-H, Davila-Garcia MI, Gbadegesin M, Vicini S, Wolfe BB (1996) Regional and ontogenetic expression of the NMDA receptor subunit NR2D protein in rat brain using a subunit-specific antibody. J Neurochem 67:2335-2345.

Dunah AW, Yasuda RP, Wolfe BB (1998) Developmental regulation of tyrosine phosphorylation of the NR2D NMDA glutamate receptor subunit in the rat central nervous system. J Neurochem 71:1926-1934.

Dunah AW, Wang Y-H, Yasuda RP, Kameyama K, Huganir RL, Wolfe BB, Standaert DG (2000a) Alterations in subunit expression, composition, and phosphorylation of striatal $N$-methyl-D-aspartate glutamate receptors in a rat 6-OHDA model of Parkinson's disease. Mol Pharmacol 57:342-352.
Dunah AW, Wyszynski M, Martin DM, Sheng M, Standaert DG (2000b) $\alpha$-Actinin-2 in rat striatum: localization and interaction with NMDA glutamate receptor subunits. Brain Res Mol Brain Res 79:77-87.

Engber TM, Papa SM, Boldry RC, Chase TN (1994) NMDA receptor blockade reverses motor response alterations induced by levodopa. NeuroReport 5:2586-2588.

Grant SG, O’Dell TJ, Karl KA, Stein PL, Soriano P, Kandel ER (1992) Impaired long-term potentiation, spatial learning, and hippocampal development in fyn mutant mice. Science 258:1903-1910.

Gurd JW (1985) Phosphorylation of the postsynaptic density glycoprotein gp180 by endogenous tyrosine kinase. Brain Res 333:385-388.

Hayashi Y, Shi SH, Esteban JA, Piccini A, Poncer JC, Malinow R (2000) Driving AMPA receptors into synapses by LTP and CaM KII: requirement for GluR1 and PDZ domain interaction. Science 287:2262-2267.

Hisatsune C, Umemori H, Inoue T, Michikawa T, Kohda K, Mikoshiba K, Yamamoto T (1997) Phosphorylation-dependent regulation of $N$-methyl-D-aspartate receptors by calmodulin. J Biol Chem 272:20805-20810.

Kaur S, Starr MS (1997) Differential effects of intrastriatal and intranigral injections of glutamate antagonists on motor behaviour in the reserpine-treated rat. Neuroscience 76:345-354.

Kennedy MB (1993) The postsynaptic density. Curr Opin Neurobiol 3:732-737.

Kim E, Cho K-O, Rothschild A, Sheng M (1996) Heteromultimerization and NMDA receptor-clustering activity of chapsyn-110, a member of the PSD-95 family of proteins. Neuron 17:103-113.

Klockgether T, Turski L (1990) NMDA antagonists potentiate antiparkinsonian actions of L-DOPA in monoamine-depleted rats. Ann Neurol 28:539-546.

Köhr G, Seeburg PH (1996) Subtype-specific regulation of recombinant NMDA receptor channels by protein tyrosine kinases of the src family. J Physiol (Lond) 492:445-452.

Kornau HC, Schenker LT, Kennedy MB, Seeburg PH (1995) Domain interaction between NMDA receptor subunits and the postsynaptic density protein PSD-95. Science 269:1737-1740.

Lan J, Skeberdis VA, Jover T, Grooms SY, Lin Y, Araneda RC, Zheng X, Bennett MV, Zukin RS (2001) Protein kinase C modulates NMDA receptor trafficking and gating. Nat Neurosci 4:382-390.

Lau LF, Huganir RL (1995) Differential tyrosine phosphorylation of $N$-methyl-D-aspartate receptor subunits. J Biol Chem 270:20036-20041.

Laurie DJ, Seeburg PH (1994) Ligand affinities at recombinant $N$-methyl-D-aspartate receptors depend on subunit composition. Eur J Pharmacol 268:335-345.

Lin JW, Wyszynski M, Madhavan R, Sealock R, Kim JU, Sheng M (1998) Yotiao, a novel protein of neuromuscular junction and brain that interacts with specific splice variants of NMDA receptor subunit NR1. J Neurosci 18:2017-2027.

Lissin DV, Gomperts SN, Carroll RC, Christine CW, Kalman D, Kitamura M, Hardy S, Nicoll RA, Malenka RC, von Zastrow M (1998) Activity differentially regulates the surface expression of synaptic AMPA and NMDA glutamate receptors. Proc Natl Acad Sci USA 95:7097-7102.

Luo JH, Bosy TZ, Wang YH, Yasuda RP, Wolfe BB (1996) Ontogeny of NMDA R1 subunit protein expression in five regions of rat brain. Brain Res Dev Brain Res 92:10-17.

Luo JH, Wang Y, Yasuda RP, Dunah AW, Wolfe BB (1997) The majority of $N$-methyl-D-aspartate receptor complexes in adult rat cerebral cortex contain at least three different subunits (NR1/NR2A/NR2B). Mol Pharmacol 51:79-86.

Lynch DR, Gallagher MJ (1996) Inhibition of $N$-methyl-D-aspartate receptors by haloperidol: developmental and pharmacological characterization in native and recombinant receptors. J Pharmacol Exp Ther 279:154-161.

Lynch DR, Anegawa NJ, Verdoorn T, Pritchett DB (1994) $N$-methyl-Daspartate receptors: different subunit requirements for binding of glutamate antagonists, glycine antagonists, and channel-blocking agents. Mol Pharmacol 45:540-545.

Marin C, Papa S, Engber TM, Bonastre M, Tolosa E, Chase TN (1996) MK-801 prevents levodopa-induced motor response alterations in parkinsonian rats. Brain Res 736:202-205.

Monyer H, Burnashev N, Laurie DJ, Sakmann B, Seeburg PH (1994) Developmental and regional expression in the rat brain and functional properties of four NMDA receptors. Neuron 12:529-540.

Moon IS, Apperson ML, Kennedy MB (1994) The major tyrosinephosphorylated protein in the postsynaptic density fraction is $N$-methylD-aspartate receptor subunit 2B. Proc Natl Acad Sci USA 91:3954-3958.

Morelli M, Fenu S, Pinna A, Di Chiara G (1992) Opposite effects of NMDA receptor blockade on dopaminergic D1- and D2-mediated behavior in the 6-hydroxydopamine model of turning: relationship with c-fos expression. J Pharmacol Exp Ther 260:402-408.

Nishimune A, Isaac JTR, Molnar E, Noel J, Nash SR, Tagaya M, Collingridge GL, Nakanishi S, Henley JM (1998) NSF binding to GluR2 regulates synaptic transmission. Neuron 21:87-97.

Oh JD, Russell DS, Vaughan CL, Chase TN (1998) Enhanced tyrosine 
phosphorylation of striatal NMDA receptor subunits: effect of dopaminergic denervation and L-DOPA administration. Brain Res 813.

Osten P, Ziff EB (1999) AMPA receptor forms a biochemically functional complex with NSF and $\alpha$ - and $\beta$-SNAPs. Ann NY Acad Sci 868:558-560.

Papa SM, Chase TN (1996) Levodopa-induced dyskinesias improved by a glutamate antagonist in parkinsonian monkeys. Ann Neurol 39:574-578.

Papa SM, Engber TM, Boldry RC, Chase TN (1993) Opposite effects of NMDA and AMPA receptor blockade on catalepsy induced by dopamine receptor antagonists. Eur J Pharmacol 232:247-253.

Papa SM, Boldry RC, Engber TM, Kask AM, Chase TN (1995) Reversal of levodopa-induced motor fluctuations in experimental parkinsonism by NMDA receptor blockade. Brain Res 701:13-18.

Petralia RS, Yokotani N, Wenthold RJ (1994) Light and electron microscope distributions of the NMDA receptor subunit NMDAR1 in the rat nervous system using a selective anti-peptide antibody. J Neurosci 14:667-696.

Rao A, Craig AM (1997) Activity regulates the synaptic localization of the NMDA receptor in hippocampal neurons. Neuron 19:801-812.

Roche KW, Standley S, McCallum J, Ly CD, Wenthold RJ (2000) NMDA receptor internalization is regulated by PSD-95. Soc Neurosci Abstr 26:1918.

Schapira AH (1998) Mitochondrial dysfunction in neurodegenerative disorders. Biochim Biophys Acta 1366:225-233.

Schoffelmeer AN, Vanderschuren LJ, De Vries TJ, Hogenboom F, Wardeh G, Mulder AH (2000) Synergistically interacting dopamine D1 and NMDA receptors mediate nonvesicular transporter-dependent GABA release from rat striatal medium spiny neurons. J Neurosci 20:3496-3503.

Scott DB, Blanpied TA, Swanson GT, Zhang C, Ehlers MD (2001) An NMDA receptor ER retention signal regulated by phosphorylation and alternative splicing. J Neurosci 21:3063-3072.

Sealfon SC, Olanow CW (2000) Dopamine receptors: from structure to behavior. Trends Neurosci 23:S34-S40.

Shi SH, Hayashi Y, Petralia RS, Zaman SH, Wenthold RJ, Svoboda K, Malinow R (1999) Rapid spine delivery and redistribution of AMPA receptors after synaptic NMDA receptor activation. Science 284:1811-1816.

Skeberdis VA, Lan J, Zheng X, Zukin RS, Bennett MV (2001) Insulin promotes rapid delivery of $N$-methyl-D-aspartate receptors to the cell surface by exocytosis. Proc Natl Acad Sci USA 98:3561-3566.

Snyder GL, Fienberg AA, Huganir RL, Greengard P (1998) A dopamine/D1 receptor/protein kinase A/dopamine- and cAMP-regulated phosphoprotein $\left(M_{\mathrm{r}} 32 \mathrm{kDa}\right) /$ protein phosphatase-1 pathway regulates dephosphorylation of the NMDA receptor. J Neurosci 18:10297-10303.

Sudhof TC (1995) The synaptic vesicle cycle: a cascade of proteinprotein interactions. Nature 375:645-653.

Suzuki T, Okumura-Noji K (1995) NMDA receptor subunits $\epsilon 1$ (NR2A) and $\epsilon 2$ (NR2B) are substrates for fyn in the postsynaptic density fraction isolated from the rat brain. Biochem Biophys Res Commun 216:582-588.

Takamori S, Riedel D, Jahn R (2000) Immunoisolation of GABAspecific synaptic vesicles defines a functionally distinct subset of synaptic vesicles. J Neurosci 20:4904-4911.

Tingley WG, Ehlers MD, Kameyama K, Doherty C, Ptak JB, Riley CT, Huganir RL (1997) Characterization of protein kinase A and protein kinase C phosphorylation of the $N$-methyl-D-aspartate receptor NR1 subunit using phosphorylation site-specific antibodies. J Biol Chem 272:5157-5166.

Vissel B, Krupp JJ, Heinemann SF, Westbrook GL (2001) A usedependent tyrosine dephosphorylation of NMDA receptors is independent of ion flux. Nat Neurosci 4:587-596.

Wan Q, Xiong ZG, Man HY, Ackerley CA, Braunton J, Lu WY, Becker LE, MacDonald JF, Wang YT (1997) Recruitment of functional $\mathrm{GABA}_{\mathrm{A}}$ receptors to postsynaptic domains by insulin. Nature 388:686-690.

Wang Y-H, Bosy TZ, Yasuda RP, Grayson DR, Vicini S, Pizzorusso R, Wolfe BB (1995) Characterization of NMDA receptor subunitspecific antibodies: distribution of NR2A and NR2B receptor subunits in the rat brain and ontogenic profile in cerebellum. $J$ Neurochem 65:176-183.

Wang YT, Salter MW (1994) Regulation of NMDA receptors by tyrosine kinases and phosphatases. Nature 369:233-235.

Williams K, Zappia A, M, Pritchett DB, Shen YM, Molinoff PB (1994) Sensitivity of the $N$-methyl-D-aspartate receptor to polyamines is controlled by NR2 subunits. Mol Pharmacol 45:803-809.

Wyszynski M, Lin J, Rao A, Nigh E, Beggs AH, Craig AM, Sheng M (1997) Competitive binding of $\alpha$-actinin and calmodulin to the NMDA receptor. Nature 385:439-442.

Wyszynski M, Kharazia V, Shanghvi R, Rao A, Beggs AH, Craig AM, Weinberg R, Sheng M (1998) Differential regional expression and ultrastructural localization of $\alpha$-actinin-2, a putative NMDA receptor anchoring protein, in rat brain. J Neurosci 18:1383-1392.

Ziff EB (1997) Enlightening the postsynaptic density. Neuron 19:1163-1174.

Zukin RS, Lan JY, Skeberdis VA, Opitz T, Bennett MVL (2000) Activation of mGluR1 regulates NMDA channel gating and recruits new NMDA receptors to the cell surface. Soc Neurosci Abstr 26:A806. 